\title{
Dynamic Modeling of HVDC for Power System Stability Assessment: A Review, Issues, and Recommendations
}

\author{
Tarek Abedin ${ }^{1}$, M. Shahadat Hossain Lipu ${ }^{2} \mathbb{D}^{D}$, Mahammad A. Hannan ${ }^{1, *(D)}$, Pin Jern Ker ${ }^{1}$, Safwan A. Rahman ${ }^{1}$, \\ Chong Tak Yaw ${ }^{3}$ (D) Sieh K. Tiong ${ }^{3}$ and Kashem M. Muttaqi ${ }^{4}$ (D)
}

1 Department of Electrical and Electronics Engineering, College of Engineering, University Tenaga Nasional, Kajang 43000, Malaysia; tarek_info99@yahoo.com (T.A.); PinJern@uniten.edu.my (P.J.K.); asafwan@uniten.edu.my (S.A.R.)

2 Department of Electrical, Electronic and Systems Engineering, University Kebangsaan Malaysia, Bangi 43600, Malaysia; lipu@ukm.edu.my

3 Institute of Sustainable Energy, University Tenaga Nasional, Kajang 4300, Malaysia; chongty@uniten.edu.my (C.T.Y.); siehkiong@uniten.edu.my (S.K.T.)

4 School of Electrical, Computer and Telecommunications Engineering, University of Wollongong, Wollongong, NSW 2522, Australia; kashem@uow.edu.au

* Correspondence: hannan@uniten.edu.my

check for updates

Citation: Abedin, T.; Lipu, M.S.H.; Hannan, M.A.; Ker, P.J.; Rahman, S.A.; Yaw, C.T.; Tiong, S.K.; Muttaqi, K.M. Dynamic Modeling of HVDC for Power System Stability Assessment: A Review, Issues, and Recommendations. Energies 2021, 14, 4829. https:// doi.org/10.3390/en14164829

Academic Editors: Nikolai Voropai and Nikita Tomin

Received: 7 June 2021

Accepted: 30 July 2021

Published: 8 August 2021

Publisher's Note: MDPI stays neutral with regard to jurisdictional claims in published maps and institutional affiliations.

Copyright: (c) 2021 by the authors. Licensee MDPI, Basel, Switzerland. This article is an open access article distributed under the terms and conditions of the Creative Commons Attribution (CC BY) license (https:// creativecommons.org/licenses/by/ $4.0 /)$.

\begin{abstract}
High-voltage direct current (HVDC) has received considerable attention due to several advantageous features such as minimum transmission losses, enhanced stability, and control operation. An appropriate model of HVDC is necessary to assess the operating conditions as well as to analyze the transient and steady-state stabilities integrated with the AC networks. Nevertheless, the construction of an HVDC model is challenging due to the high computational cost, which needs huge ranges of modeling experience. Therefore, advanced dynamic modeling of HVDC is necessary to improve stability with minimum power loss. This paper presents a comprehensive review of the various dynamic modeling of the HVDC transmission system. In line with this matter, an in-depth investigation of various HVDC mathematical models is carried out including average-value modeling (AVM), voltage source converter (VSC), and line-commutated converter (LCC). Moreover, numerous stability assessment models of HVDC are outlined with regard to stability improvement models, current-source system stability, HVDC link stability, and steady-state rotor angle stability. In addition, the various control schemes of LCC-HVDC systems and modular multilevel convertermulti-terminal direct current (MMC-MTDC) are highlighted. This paper also identifies the key issues, the problems of the existing HVDC models as well as providing some selective suggestions for future improvement. All the highlighted insights in this review will hopefully lead to increased efforts toward the enhancement of the modeling for the HVDC system.
\end{abstract}

Keywords: dynamic modeling; VSC-HVDC; multilevel HVDC; stability; modular multilevel converter; line commuted converter; control strategies

\section{Introduction}

The subject of power system dynamics and stability is a hot topic with a large volume of documented literature [1-5]. In current years, the stability of power systems and energy usage has stepped forward using a high-voltage DC (HVDC) energy transmission approach. Since high-voltage AC (HVAC) has shortcomings related to high transmission loss, the development of HVDC modeling and control methods can be employed in the power transmission system to enhance the entire power system stability [6-9]. The advancements in power electronics (PE) interfaced devices incorporated into energy systems support the HVDC system with regard to efficient operations and control $[10,11]$. The modeling of a PE-interfaced HVDC system decreases the modeling complexity and computational burden in simulations. Moreover, HVDC is a regularly used technique containing lots of 
huge-scale power system components [12]. The traditional line-commutated converterhigh-voltage direct current (LCC-HVDC) transmission structures are broadly utilized in the energy transmission because of the benefits of having the asynchronous AC grid link and the ability of bulk energy transmission over an extended distance [13,14].

The various control schemes of VSC-HVDC and LCC-HVDC structures on smallsign durability are explored in $[15,16]$. In line with that, the performance of control techniques of VSC-HVDC is enhanced with multi-objective optimization $[17,18]$. The control techniques on the inverter station of the LCC-HVDC system along with the effects of a phase-locked loop (PLL) on small-signal stability are studied in [19]. The VSC-HVDC system, with the impact of different reactive power control techniques on a small signal, is analyzed [20]. It is reported that the stability of P- $\mathrm{V}_{\mathrm{ac}}$ command-based VSC-HVDC illustrates high stability under vulnerable AC grids in comparison to the P-Q control when reactive power is adjusted so that it will hold the preferred voltage [21]. A more recent unique and encouraging technique is the dynamic phasor model, which includes facts controllers and HVDC transmission structures [22]. The dynamic phasor design can preserve the dynamic functions of power electronics devices (PEDs) by trimming unnecessary higher-order elements and retaining just the considerable elements [23]. The modular multilevel converter (MMC) has grown to be an attractive converter that is widely applied in excessive energy storage as well as excessive voltage applications, especially for VSC-HVDC systems [24]. The VSC (especially MMC) is more appropriate for constructing DC grids through supplying more grid services [25] even though the line-commutated converter (LCC)-based HVDC technology dominates in providing long-distance energy and bulk electricity transmission [26,27]. Several LCC-based MTDC structures were explored and analyzed in $[14,28,29]$.

The HVDC transmission integrated with VSC has proven to be efficient in the power transmission system; nevertheless, it has a shortcoming when a very weak AC signal is interfaced with the DC system [30,31]. When a fault takes place in an HVDC transmission system connected to the AC grid with a weak signal, it is challenging to deliver the reactive power at the required level, resulting in a serious problem such as voltage distortion [32]. Additionally, the converter cannot work satisfactorily and hence exhibits slow recovery and commutation failure. To overcome the aforesaid issues, numerous control schemes of VSC-based HVDC systems have been reported in the literature. However, the control operation of VSC-HVDC needs to be performed effectively to achieve accurate results including converter output frequency, reactive power, and active power. Thus, several HVDC models are introduced to improve the stability, reliability, and controllability under different possible scenarios that might happen in the power system.

This article represents the diversity of models that are possible for HVDC systems and applied to VSC HVDC system type studies. The multi-level form utilized in VSC valves extends the amount of switching components in electromagnetic transient (EMT) studies and makes the standard simulation methods ineffective [33]. From a DC Grid perspective, full physics models, full detailed models, and models based on simplified switchable resistance are not appropriate for DC grid operation studies. Full detailed models and models based on simplified switchable resistance EMT models are utilized for HVDC LCC system studies. Unique EMT simulation approaches (the detailed equivalent model) have been promoted to support VSC MMC advancements [34]. The average value model and phasor simulation models have advanced applications for VSC MMC valve arrangements. However, in the diversity of MMC VSC converter topologies, the consistent control, and power electronic interface can solve the simulation trouble into functional levels [35]. This control hierarchy policy is already utilized in power electronic building blocks [36] and may be extended to HVDC VSC. Table 1 shows several HVDC configurations with their topology in addition to merits and demerits. 
Table 1. Summary of different HVDC models configurations and merits and demerits.

\begin{tabular}{|c|c|c|c|c|c|c|c|}
\hline $\begin{array}{l}\text { Types of } \\
\text { Models }\end{array}$ & $\begin{array}{l}\text { MPWM } \\
\text { VSC }\end{array}$ & HBMMC & $\begin{array}{c}\text { HBMMC } \\
\text { \& } \\
\text { PSPWM }\end{array}$ & FBMMC & HHFB & Merits & Demerits \\
\hline $\begin{array}{l}\text { Full detailed } \\
\text { models and } \\
\text { models based } \\
\text { simplified } \\
\text { switchable } \\
\text { resistance }\end{array}$ & YES & $\mathrm{NO}(\mathrm{EM}$ & is almost $\mathrm{r}$ & gligible) & $\mathrm{NO}$ & $\begin{array}{l}\text { Computer capabilities } \\
\text { and numerical } \\
\text { techniques. Used to } \\
\text { validate simplified } \\
\text { models. Reduce } \\
\text { simulation time. }\end{array}$ & $\begin{array}{l}\text { Simulation takes } \\
\text { several days to } \\
\text { simulate an event of } \\
\text { only a few seconds. } \\
\text { Cannot accurately } \\
\text { handle switching } \\
\text { losses. Large number } \\
\text { of electrical nodes to } \\
\text { solve. }\end{array}$ \\
\hline $\begin{array}{l}\text { Detailed } \\
\text { Equivalent } \\
\text { model }\end{array}$ & NA & YES & YES & YES & $\mathrm{NO}$ & $\begin{array}{l}\text { Less computational } \\
\text { time; Limit number of } \\
\text { nodes }\end{array}$ & $\begin{array}{l}\text { Drastically reduce the } \\
\text { time required to } \\
\text { simulate MMCs }\end{array}$ \\
\hline $\begin{array}{l}\text { Discretized } \\
\text { Average } \\
\text { value model }\end{array}$ & YES & YES & YES & YES & YES & $\begin{array}{l}\text { This model is quite } \\
\text { fast because switching } \\
\text { need not to be } \\
\text { modeled. }\end{array}$ & $\mathrm{N} / \mathrm{A}$ \\
\hline $\begin{array}{c}\text { Average } \\
\text { value model }\end{array}$ & YES & YES & YES & YES & $\mathrm{NO}$ & $\begin{array}{l}\text { Switching harmonic } \\
\text { improves the accuracy. }\end{array}$ & $\begin{array}{c}\text { Fundamental } \\
\text { frequency might be } \\
\text { sufficient. }\end{array}$ \\
\hline $\begin{array}{l}\text { Phasor } \\
\text { model }\end{array}$ & YES & YES & YES & YES & YES & $\begin{array}{l}\text { Performed with } \\
\text { time-domain or } \\
\text { frequency-domain. } \\
\text { All harmonics are } \\
\text { neglected. }\end{array}$ & $\begin{array}{l}\text { Develop unbalanced } \\
\text { configurations due to } \\
\text { the dynamic behavior } \\
\text { after unsymmetrical } \\
\text { faults. }\end{array}$ \\
\hline
\end{tabular}

MLPWM: Multi-level PWM; HBMMC: Half bridge MMC; PSPWM: Phase shifted PWM; FBMMC: Full bridge MMC; HHFB: Hybrid half and full bridge.

This paper aims to offer a detailed presentation of HVDC modeling, various assessment models, control schemes, and related issues and limitations. The key contributions of this paper are listed below.

- The model of HVDC models developed with VSC application and their precise control strategies with numerous characteristics are explained in Table 2. Various kinds of computational models for the simulation of VSC are described with their applicability as it is the building block of future grids.

- In this paper, distinguished levels of dynamic HVDC models are explained thoroughly to deliver a reliable stability estimation in complex mixed AC or DC systems. This exhibits the trade-off between the correctness of dynamic responses and the complexity of the HVDC dynamic models.

- Various control models have been studied in both single and multi-infeed including LCC-HVDC and MMC-MTDC highlighting the execution process, strengths, and weaknesses. Nevertheless, there are some methodological difficulties while implementing the MMC to DC transmission system.

- Existing issues and limitations of HVDC modeling with regard to inverter, reactive power, frequency, harmonics, and switching issues are highlighted.

- Based on existing constraints, future recommendations are provided for the development of advanced HVDC modeling as well as further investigation of HVDC preference in different levels of power and voltage applications. 
Table 2. Summary of various VSC models.

\begin{tabular}{|c|c|c|c|}
\hline $\begin{array}{l}\text { Type of } \\
\text { Model }\end{array}$ & $\begin{array}{l}\text { Relative } \\
\text { Computing } \\
\text { Times }\end{array}$ & Type of Simulation & Tools Type of Studies \\
\hline Full Physics-Based Models & $\mathrm{N} / \mathrm{A}$ & Circuit simulation tools & Not suitable for grid studies \\
\hline Full Detailed Models & 1000 & EMT & $\begin{array}{l}\text { Comprehensive examinations of faults } \\
\text { in submodules; Applied to verify } \\
\text { simplified models }\end{array}$ \\
\hline $\begin{array}{l}\text { Models based on simplified } \\
\text { switchable resistances }\end{array}$ & 900 & EMT & $\begin{array}{l}\text { Comprehensive examinations of faults } \\
\text { in submodules; Applied to verify } \\
\text { simplified models }\end{array}$ \\
\hline $\begin{array}{l}\text { Detailed Equivalent Circuit } \\
\text { Models }\end{array}$ & 30 & EMT & $\begin{array}{c}\text { Detailed studies of AC and DC fault } \\
\text { close to the converter }\end{array}$ \\
\hline $\begin{array}{l}\text { Detailed Equivalent Circuit } \\
\text { Models }\end{array}$ & 2 & EMT & $\begin{array}{c}\text { Studies of AC and DC } \\
\text { transients-high-level control system } \\
\text { design-harmonic studies }\end{array}$ \\
\hline $\begin{array}{c}\text { Simplified Average Value } \\
\text { Models }\end{array}$ & $\begin{array}{l}1.5 \\
0.1\end{array}$ & $\begin{array}{c}\text { EMT } \\
\text { Phasor domain }\end{array}$ & Studies of AC and DC transients \\
\hline RMS Load-Flow Models & 0.01 & Load-flow tools & Power-flow \\
\hline
\end{tabular}

The article is arranged into six sections. The reviewing methodology is outlined in Section 2. The overview of the modeling of the HVDC system is presented in Section 3. The stability assessment models in HVDC are described in Section 4. The existing issues and challenges are explored in Section 5 . The concluding remarks and valuable suggestions are highlighted in Section 6.

\section{Reviewing Methodology}

This review paper was written based on content analysis. The suitable articles related to HVDC modeling were chosen using the three screening steps. The first screening and evaluation was the literature survey where the related articles were selected using different platforms such as Web of Science, Google Scholar, Scopus databases, IEEE Xplore, and ScienceDirect. The results revealed that a total of 428 articles were found in the first screening. The second screening was carried out using important keywords. Six keywords were selected to search for suitable literature, which were high-voltage direct current, average-value modeling, line commutated converter, Voltage Source Converter, Modular multilevel converter, and multi-terminal direct current. In addition to keywords, we considered article title, contents, abstracts, and novelty to find the relevant works. The results indicated that a total of 284 articles were identified through the second screening. The third screening was conducted based on the citations, impact factors, and the review process. A total of 130 articles were found and analyzed, which were published in notable journals, conference proceedings, books, and reports. These 130 articles were examined in detail to deliver a critical review, analysis, and discussion relating to HVDC modeling, stability assessment, control strategies, issues, and challenges. The schematic illustration of the reviewing methodology is shown Figure 1.

The key analysis and results achieved are arranged through the three-screening process into five groups. Firstly, various HVDC models were reviewed in detail. Secondly, the stability assessment models of HVDC were highlighted. Thirdly, control schemes of HVDC modeling were explored. Fourthly, numerous open issues of HVDC modeling were identified. Lastly, the review offered some important proposals for future improvement of HVDC modeling towards efficient energy transmission and management. 


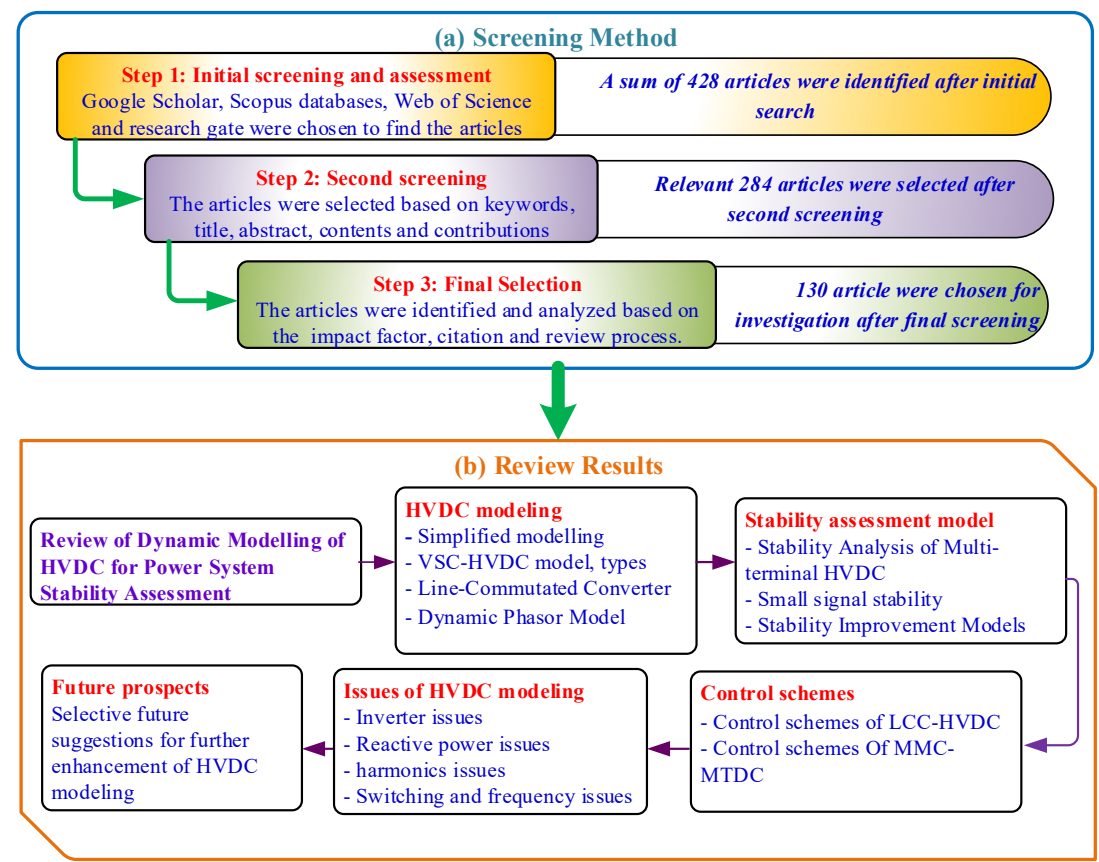

Figure 1. Schematic design of the reviewing methodology (a) Screening method (b) Review results.

\section{Overview of Modeling of HVDC System}

This section presents the various modeling concept of HVDC systems including simplified HVDC modeling, the dynamic average-value modeling (AVM)-based HVDC system, and the VSC-based HVDC model.

\subsection{Simplified Modeling of HVDC Systems}

Usually, various power electronic devices are utilized to operate the grid-integrated offshore wind energy system. The wind technology is taken into consideration as a negative load with a massive range of energy while in HVDC structures, each LCC and VSC is considered as the constant energy loads associated with the rectifier and inverter [37]. The sending end, the bus $i$, links the positive energy load where the electricity is transferred for DC operation from the grid. In contrast, the receiving end, bus $j$, connects the negative energy load where the energy is converted to AC mode from DC mode. The connection among active energy at the transmitting and receiving end may be defined as $\mathrm{pi}=-\mathrm{pj}$. Figure 2 presents a simplified injection model of an HVDC system where indexes $i$ and $\mathrm{j}$ stand for transmitting and receiving end buses [38]. The AC voltage value and voltage angle are denoted by $U$ and $\theta$, respectively. The active energy and reactive energy are characterized by $\mathrm{P}$ and $\mathrm{Q}$, respectively, at every bus.

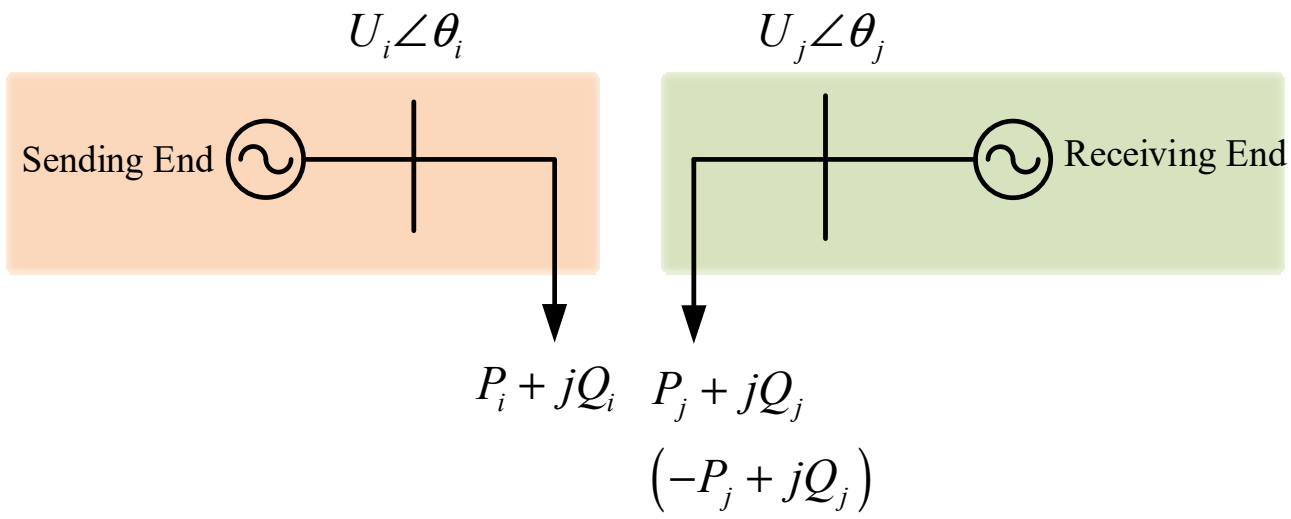

Figure 2. A simplified HVDC system model. 


\subsection{Dynamic AVM of HVDC Systems}

This section narrates the dynamic modeling of HVDC structures, features including LCC-HVDC and VSC-HVDC. Figure 3 presents the dynamic modeling of the HVDC structure, which is used to describe the steady-state and transient characteristics of various currents [39]. The inverter current control is used to control the energy based on the current margin $\left(I_{d c_{-} \_ \text {ref }} I_{\text {margin }}\right)$, which is assigned to $0.1-0.15 \mathrm{pu}$. The control operation between DC current and DC voltage is functioned using a current error control (CEC), which is further used to inject the extinction angle control and DC current control $[40,41]$. The inverter operation at the minimal extinction angle is performed by the inverter control mode to reduce the reactive energy dissipation and harmonic level [42].

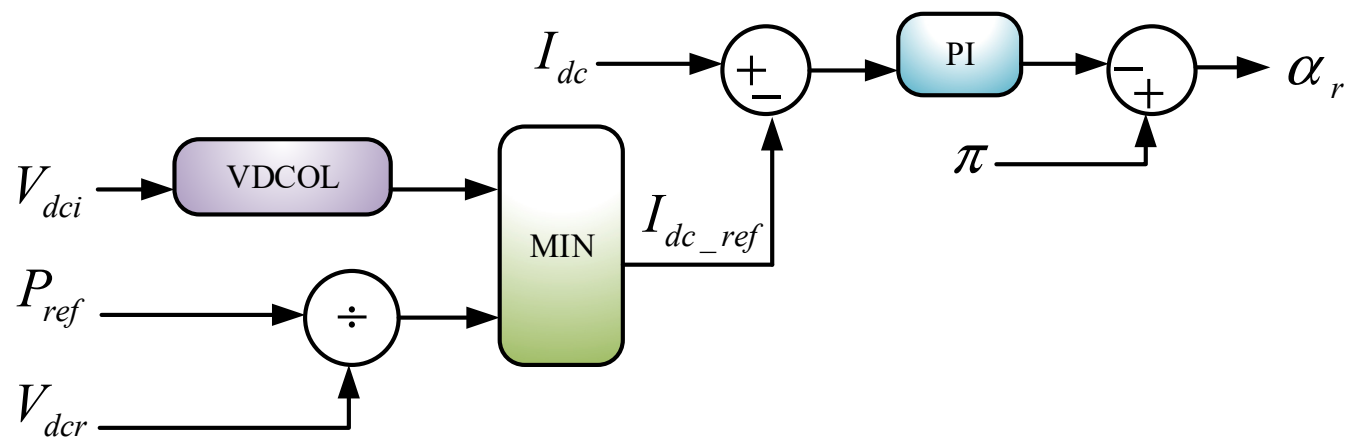

Figure 3. Rectifier DC current control operation.

\section{(1) VSC-HVDC MODEL}

The VSC-based HVDC system has provided numerous benefits in comparison to LCCHVDC including harmonic content material, impartial control of active and reactive power, and limited black-start functionality [43-46]. The functional capability of VSC-HVDC is explained using a half-bridge modular multilevel converter (MMC) [47-49]. Generally, an array of sub-modules (SMs) is used to design a half-bridge MMC-based VSC-HVDC system, which is connected in series to every converter arm, as depicted in Figure 4 [50]. Every SM is designed using a half-bridge converter with insulated-gate bipolar transistors (IGBTs) and one parallel capacitor. The CIGRE recommendations are used to build the dynamic version of a half-bridge MMC-HVDC system [51]. The VSC-HVDC under the dynamic AVM exhibits advantages such as it does not include switching consequences, harmonics, and power stability [52]. The operation in every SM follows the executions of the stage half-bride converter. The output voltage $\left(V_{s m}\right)$ equals capacitor voltage when the $\mathrm{SM}$ is attached or bypassed. However, the output voltage is 0 when SM is passed. The AC voltage waveform is generated with the support of sequentially switching series-linked SMs $[53,54]$. The AC voltage at the converter terminal is controlled by varying the voltages, which is expressed using (1).

$$
V_{a}=\frac{V_{l a}-V_{u a}}{2}-L_{a r m} \frac{d I_{a}}{d t}-\frac{R_{a r m}}{2} I_{a}
$$

- Mathematical modeling of VSC HVDC

The mathematical modeling of VSC HVDC is shown in Figure 5 [55]. The dynamic equations of the inverter in per unit (pu) are expressed in (2) and (3). The inverter filter and grid are shown in (4) and (5), respectively, in which $\omega \mathrm{b}$ and $\omega \mathrm{g}$ denote the base angular grid frequency and grid frequency in $\mathrm{pu}$, respectively.

$$
\begin{gathered}
\frac{d i_{L}}{d t}=\frac{\omega b}{L_{C}}-v_{C V}-\frac{\omega b}{L_{C}} v_{0}-\left(\frac{R_{C}}{L_{C}}+j_{w g}\right) i_{L} \\
\frac{d v_{d c}}{d t}=\frac{\omega b}{C_{d c}} i_{d c, \text { line }}-\frac{\omega b}{C_{d c}} i_{d c}
\end{gathered}
$$




$$
\begin{gathered}
\frac{d v_{0}}{d t}=\frac{\omega b}{C_{f}} i_{L}-\frac{\omega b}{C_{f}} i_{0}-j \omega_{b} \omega_{g} v_{0} \\
\frac{d i_{0}}{d t}=\frac{\omega b}{L_{g}} v_{0}-\frac{\omega b}{L_{g}} V_{g}-\omega_{b}\left(\frac{R_{g}}{L_{g}}+j \omega_{g}\right) i_{g}
\end{gathered}
$$

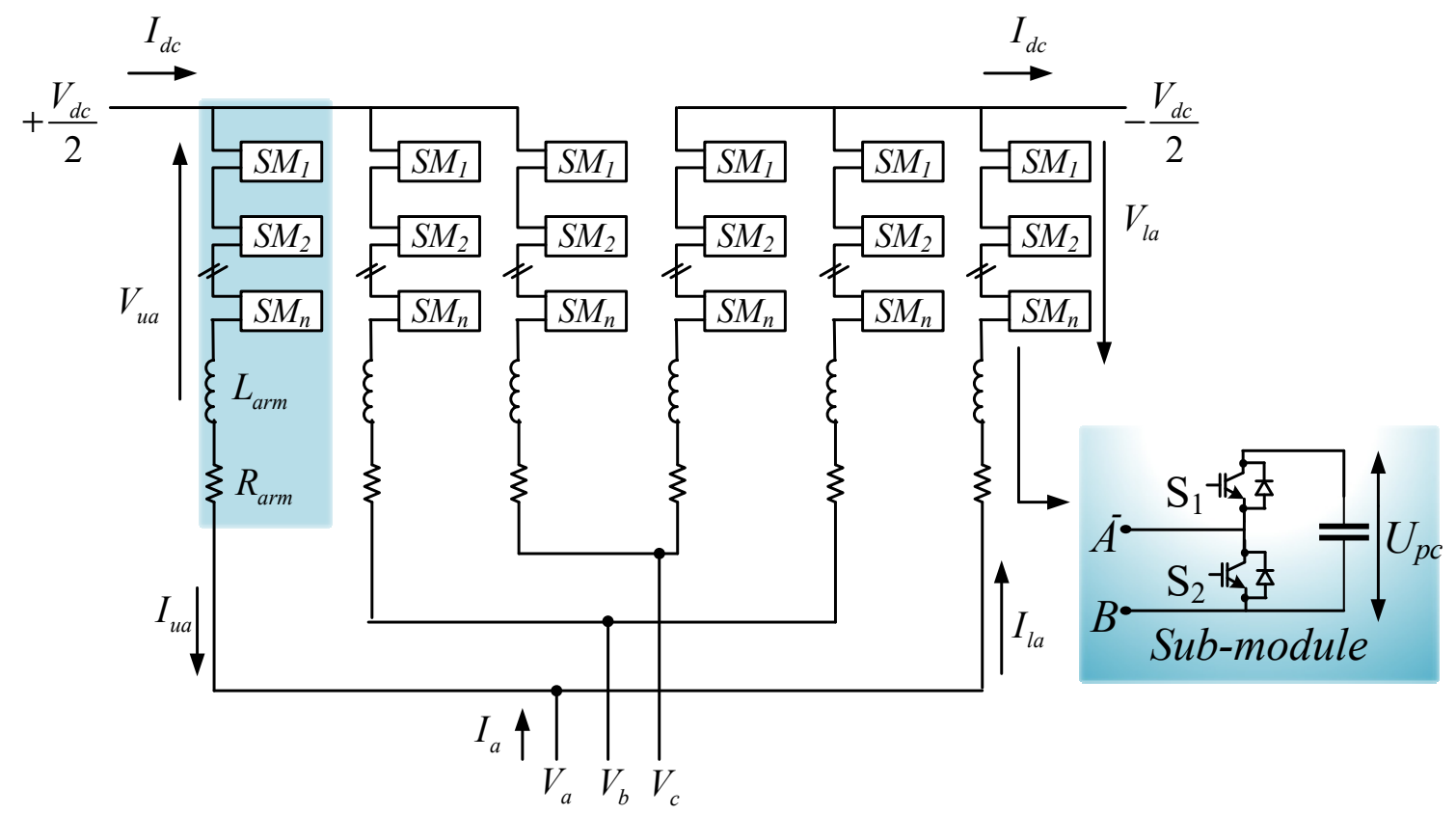

Figure 4. MMC topology for the three-phase converter.

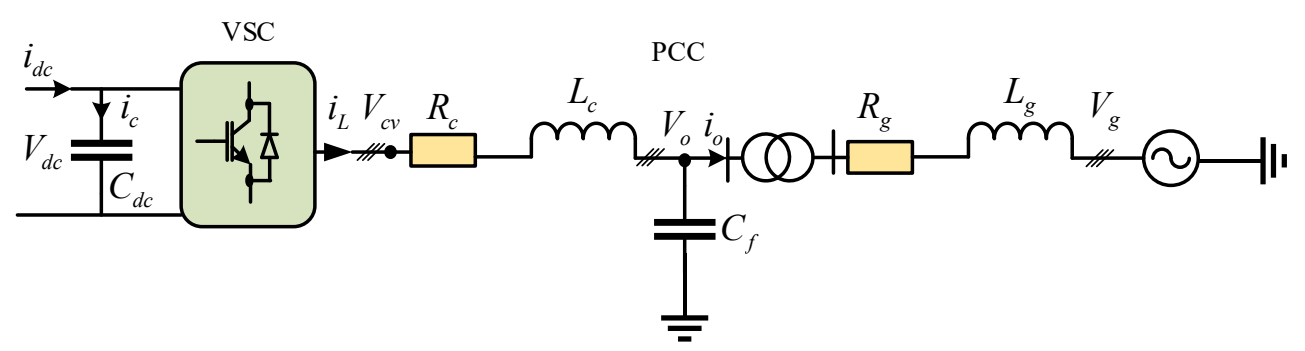

Figure 5. Structure of the VSC-based HVDC converter connected to the AC system.

The modeling, evaluation, and control operation can be provided in a synchronous reference frame (SRF). The transformation of the three-section quantity from the stationary reference frame to SRF is primarily based on the amplitude-invariant Park transformation, with the $\mathrm{d}$-axis aligned with the voltage vector $\mathrm{v}_{0}$ and $\mathrm{q}$-axis main the $\mathrm{d}$-axis through 90 degrees. Accordingly, energy stability constraints among DC and AC links can be performed using the following formula.

$$
i_{d c} v_{d c}=i_{L d} v_{c v d}+i_{L q} v_{c v q}
$$

\section{- $\quad$ Types of VSC HVDC Models}

This section focuses on the description of different types of computational models for the simulation of VSC for future DC grids. Several types of electromagnetic-transients (EMT) and phasor models can be designed depending upon the time frame of aspects being investigated on the DC grid. A summary of the character of those models is illustrated beside their applicability.

Type 1: Type 1 refers to the full physics-based models that uses the incomplete differential mathematical expressions that can be applied to design a lumped in IGBT 
applications. In [56], a complicated IGBT sub-circuit is recommended and analyzed toward a limited component design. Those complicated designs can correctly signify switching losses; nevertheless, they need notably small-time steps for the reason that the switching function happens across a remarkably precise duration. Although Type 1 models might also allow excellent correctness, these models are not normally utilized for simulations in energy system because of extreme computing duration demands.

Type 2: Type 2 denoted the detailed nonlinear IGBT-based model that forms the IGBT valves by utilizing a perfect controlled switch, two imperfect diodes, and a snubber circuit, as displayed in Figure 6 [57]. The imperfect diodes are represented with nonlinear resistances applying the standard V-I curvature of a diode. The nonlinear component can be modified in step with the manufacturer record.

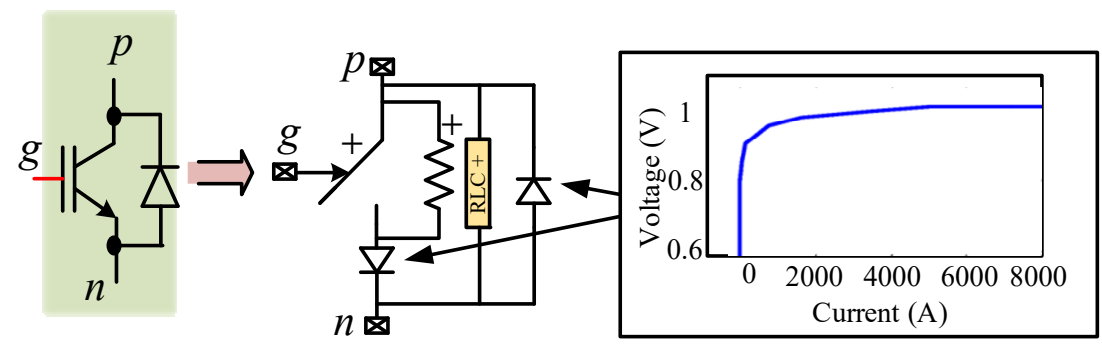

(a)

(b)

Figure 6. (a) Illustration of a nonlinear IGBT valve. (b) Diode V-I characteristics.

Type 3: Type 3 presents the simplified IGBT-based model that integrates the IGBT device and its anti-parallel diode. This structure operates under a bidirectional switch with the aid of two-state resistances $R_{\mathrm{ON}}$ and $\mathrm{R}_{\mathrm{OFF}}$. Therefore, $\mathrm{R}_{1}$ and $\mathrm{R}_{2}$ values rely upon signals, the current path, and the capacitor voltage, as shown in Figure 7 [57].

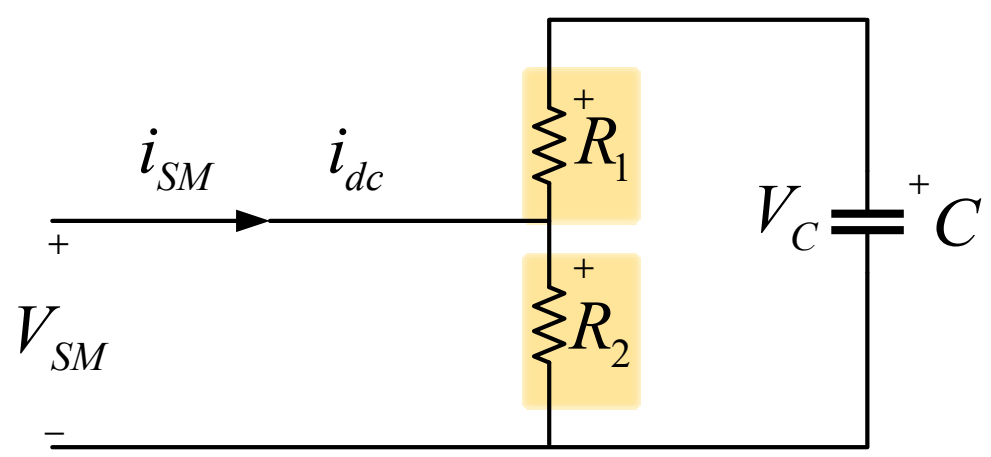

Figure 7. The structure of the submodule with the simplified IGBT model.

Type 4: Type 4 depicts the detailed equivalent-circuit-based model that uses the simple circuit with the required modification. This type of configuration is built using a Thevenin equivalent for every arm of the converter without considering the inner central nodes [58]. The equivalent circuit supports decreasing the computational execution of the model.

Type 5: Type 5 presents the AVM based on switching functions that applies the MMC function to control voltage and current supply. In this layout, the IGBT is not perfectly expressed. The current possible AVM pretends that each one of the inner variables inside the MMC is correctly managed, every SMs capacitor voltage is stable, and the circulating currents in the second harmonic under every phase are contained. Consequently, the balancing control algorithm (BCA) and circulating current suppression control (CCSC) 
blocks are eliminated. Depending on the procedure [37], the resulting equalizations are determined for every phase $j$, as expressed in the following equations

$$
\begin{aligned}
& v_{u j}=\frac{v_{d c}}{2}-L_{a r m} \frac{d i u j}{d t}-v j \\
& v_{l j}=\frac{v_{d c}}{2}-L_{a r m} \frac{d i u j}{d t}+v j
\end{aligned}
$$

where $j=a, b$, c. The higher and lower arm currents can be written in the following equation considering the value of circulating current is predicted to be zero,

$$
i_{u j}=\frac{I_{d c}}{3}-\frac{i_{j}}{2}, i_{l j}=\frac{I_{d c}}{3}+\frac{i_{j}}{2}
$$

The combination of (7) and (8) results in

$$
v_{u j}=e \operatorname{conv} v_{j}+\frac{v_{d c}}{2}, v_{l j}=-e \operatorname{conv} v_{j}+\frac{v_{d c}}{2}
$$

where econv $v_{j}=\left(v_{u j}-v_{l j}\right) / 2$.

The current representing the converter loss is expressed as follows,

$$
I_{\text {loss }}=P_{\text {loss }} / V_{d c}=R_{\text {loss }}\left(I^{\prime} d c\right)^{2} / V_{d c}
$$

The equivalent resistance of MMC is denoted by $R_{\text {loss }}$, which includes resistive and switching losses. The equivalent DC current is indicated by $I / d c$, which contains converter losses. The expression for DC current is determined from (12),

$$
I_{d c}=I_{d c}^{\prime}-I_{l o s s}
$$

A series diode is connected on the DC-side design of the AVM to force the DC current flow route.

Type 6-RMS Load-Flow Models-Load flow models will apply steady-state converter outputs. The specific transients are not modeled and the HVDC system lessens to a model of its steady-state output values [59,60].

Table 2 summarizes calculation speed performances of various VSC models and the types of studies and the corresponding tools.

(2) Line-Commutated Converter-Based HVDC

The design of a monopolar LCC-HVDC system, related to the primary CIGRE HVDC system, is presented in Figure 8 [22]. Filter banks and associated transformers are interfaced with the HVDC converter blocks to the AC side at the inverter and rectifier. The AC side operations are executed by Thevenin circuits, which are defined using the useful shortcircuit ratio (ESCR). The harmonized (11th and 13th harmonics) and high-pass filters eliminate more leading frequency components as well as provide the expected reactive power of the converters, leading to a lagging power factor at each end.

\section{- Control Strategies Of LCC-HVDC Systems}

The various control variables blocks are applied, such as the inverter current controller, the inverter, the gamma controller, and the rectifier current controller as denoted in Figure 9 [22]. Generally, the rectifier controls the DC side current, while the inverter controls the extinction-angle $[39,61,62]$. The rectifier and inverter control operations are defined by proportional-integral (PI) controllers running upon the DC current and the inverter extinction angle. The voltage-dependent current order limit (VDCOL) decreases the DC current order while AC voltage is used to defend the valves. Although HVDC models include active power and reactive power, the control procedures within the HVDC models are diverse and complicated. The various control schemes of the HVDC model are presented in Table 3. 


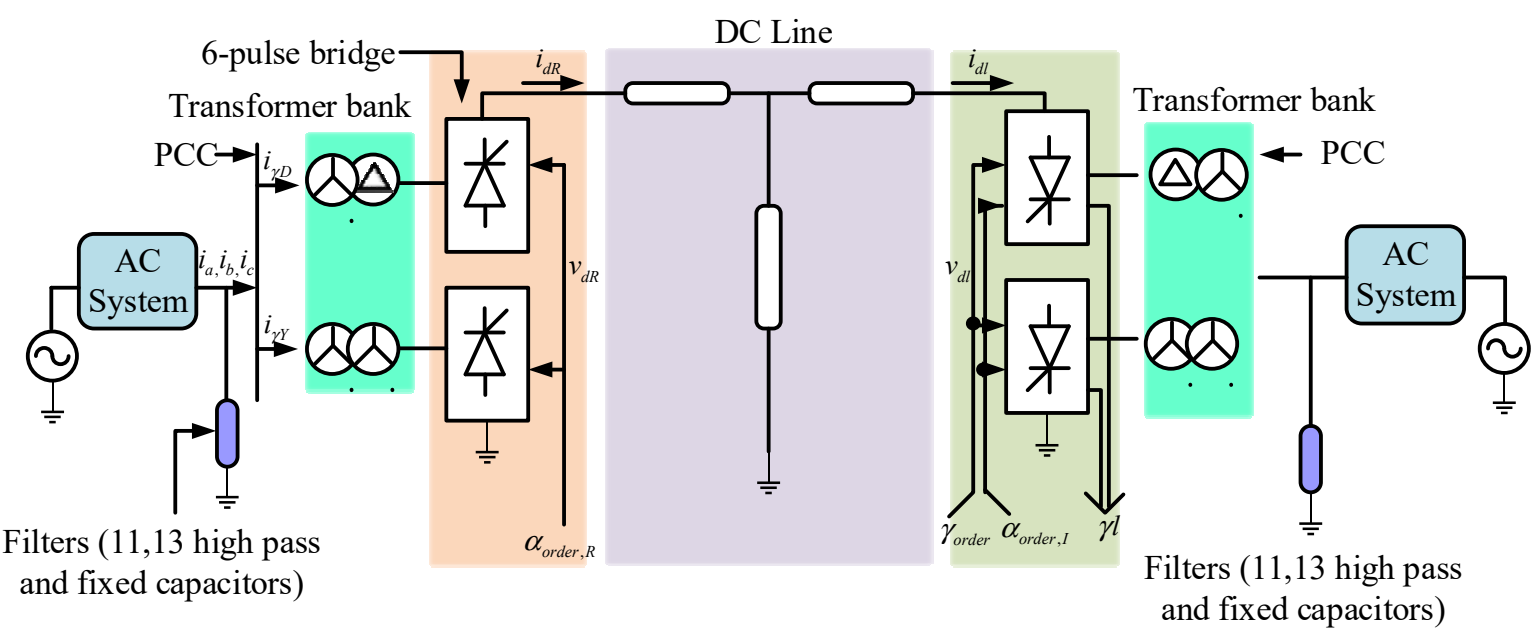

Figure 8. The configuration of a 12-pulse LCC HVDC system.

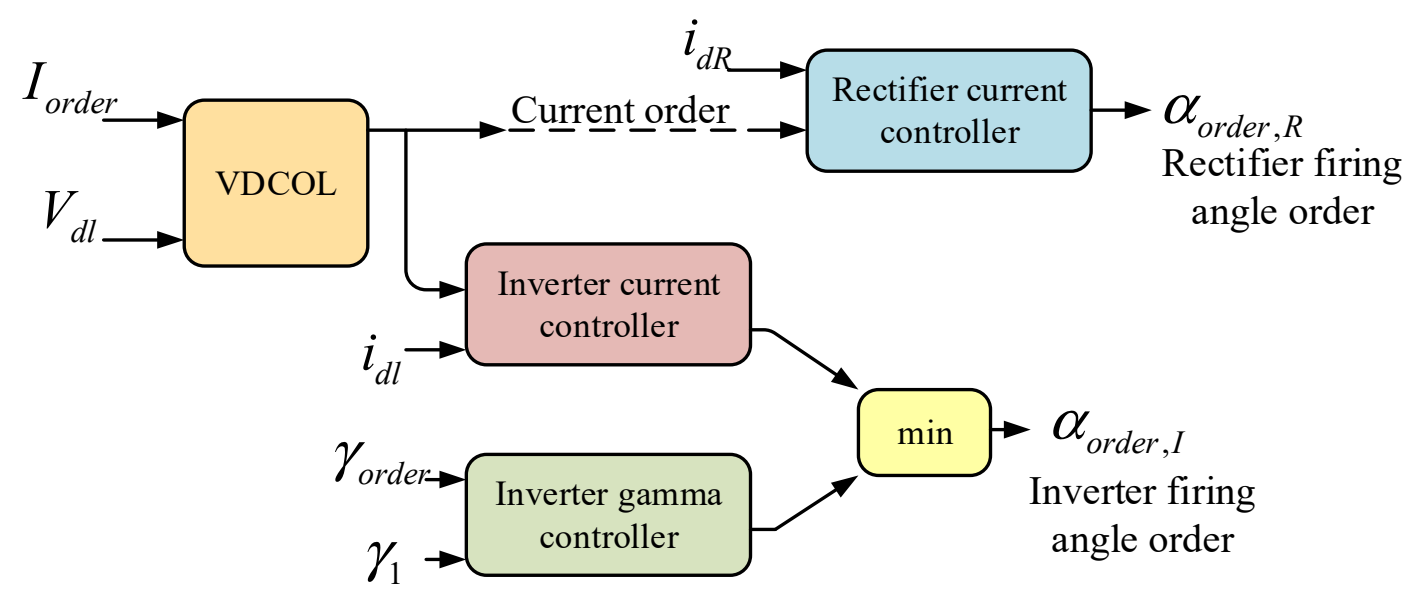

Figure 9. The operational flow diagram of the HVDC control scheme.

Table 3. Comparative study of various control strategies of HVDC.

\begin{tabular}{|c|c|c|c|c|c|}
\hline No & $\begin{array}{c}\text { Control } \\
\text { Classification }\end{array}$ & Execution & Merits & Demerits & Ref \\
\hline 1. & Voltage Controller & $\begin{array}{l}\text { Straight control power } \\
\text { angle, overactive power, } \\
\text { as well as reactive power. }\end{array}$ & $\begin{array}{l}\text { Manageable and simple } \\
\text { method. }\end{array}$ & $\begin{array}{l}\text { Reactive and active power } \\
\text { cannot be managed } \\
\text { autonomously. }\end{array}$ & {$[63,64]$} \\
\hline 2. & $\begin{array}{l}\text { Vector Current } \\
\text { Controller }\end{array}$ & $\begin{array}{l}\text { The } d-q \text { axis based } \\
\text { steady-state method to } \\
\text { manage active and } \\
\text { reactive power. }\end{array}$ & $\begin{array}{l}\text { Active dynamic reaction. } \\
\text { Performs more reliable } \\
\text { energy features under } \\
\text { harmonics and grid } \\
\text { disruptions. Defends } \\
\text { toward overcurrent fault. } \\
\text { Can repay grid harmonics. }\end{array}$ & $\begin{array}{l}\text { Cannot limit the converter } \\
\text { current leading to poor } \\
\text { execution under a } \\
\text { vulnerable AC side. }\end{array}$ & {$[65,66]$} \\
\hline 3. & $\begin{array}{l}\text { Advanced Vector } \\
\text { Current Controller }\end{array}$ & $\begin{array}{l}\text { Outer loop control } \\
\text { operation including four } \\
\text { decoupling } \\
\text { parameter-varying } \\
\text { operation and subdued } \\
\text { system non-linearity. }\end{array}$ & $\begin{array}{l}\text { More reliable } \\
\text { handleability to } \\
\text { communicate with very } \\
\text { vulnerable AC grids. }\end{array}$ & $\begin{array}{l}\text { Neglects the asymmetrical } \\
\text { fault as well as any } \\
\text { unexpected turn while } \\
\text { grid regulation. }\end{array}$ & {$[67,68]$} \\
\hline
\end{tabular}


Table 3. Cont.

\begin{tabular}{|c|c|c|c|c|c|}
\hline No & $\begin{array}{c}\text { Control } \\
\text { Classification }\end{array}$ & Execution & Merits & Demerits & Ref \\
\hline 4. & $\begin{array}{c}\text { Power } \\
\text { Synchronization } \\
\text { Controller }\end{array}$ & $\begin{array}{l}\text { Uses a phase angle and } \\
\text { voltage value to manage } \\
\text { active power and reactive } \\
\text { power, respectively } \\
\text { without PLL to manage } \\
\text { the energy } \\
\text { synchronization. }\end{array}$ & $\begin{array}{l}\text { Can support synchronism } \\
\text { among VSC and AC } \\
\text { systems. Reduces the } \\
\text { viable instability due to } \\
\text { PLL whilst correlated to a } \\
\text { vulnerable AC system. No } \\
\text { requirement to have a } \\
\text { pre-set current system as } \\
\text { well as rely upon an } \\
\text { internal current loop. }\end{array}$ & $\begin{array}{l}\text { Higher current at the } \\
\text { converter valves at some } \\
\text { point of the extreme AC } \\
\text { side fault incidence. } \\
\text { Massive load angles } \\
\text { whilst it is far internally } \\
\text { connected to an ineffective } \\
\text { AC side. }\end{array}$ & {$[69,70]$} \\
\hline 5. & $\begin{array}{l}\text { ABC Frame } \\
\text { Controller }\end{array}$ & $\begin{array}{l}\text { ABC block base VSC is } \\
\text { assigned without a PLL } \\
\text { system. The point of } \\
\text { coupling (PCC) is } \\
\text { employed to control active } \\
\text { and reactive power. }\end{array}$ & $\begin{array}{l}\text { VSC-HVDC provides } \\
\text { excellent synchronization } \\
\text { without the reference } \\
\text { output current, feedback } \\
\text { currents lag and adaptive } \\
\text { filter under inadequate } \\
\text { AC networks and the grid } \\
\text { voltage frequency } \\
\text { variation. }\end{array}$ & $\begin{array}{l}\text { Complex formation and } \\
\text { regulation to regulate } \\
\text { active and reactive power. }\end{array}$ & {$[71,72]$} \\
\hline 6. & $\begin{array}{l}\text { Voltage Droop } \\
\text { Controller }\end{array}$ & $\begin{array}{l}\text { Employs the droop } \\
\text { parameters to examine the } \\
\text { steady-state operation } \\
\text { using the inner loop } \\
\text { controls current and } \\
\text { external loop voltage } \\
\text { controls DC voltage. }\end{array}$ & $\begin{array}{l}\text { Lessen the impact of DC } \\
\text { voltage disturbances. }\end{array}$ & $\begin{array}{l}\text { Reference current control } \\
\text { ought to differ in an } \\
\text { immediate shift at some } \\
\text { stage in grid procedure. }\end{array}$ & {$[73,74]$} \\
\hline 7. & $\begin{array}{l}\text { Adaptive Back } \\
\text { Stepping } \\
\text { Controller }\end{array}$ & $\begin{array}{l}\text { The DC cable dynamics } \\
\text { are used to obtain a fixed } \\
\text { rate DC bus voltage. }\end{array}$ & $\begin{array}{l}\text { The voltage overshoot in } \\
\text { grid integrated wind farm } \\
\text { is reduced resulting in an } \\
\text { improvement in the DC } \\
\text { voltage controller } \\
\text { performance. }\end{array}$ & $\begin{array}{l}\text { Does not consider } \\
\text { uncertainties that } \\
\text { influence the whole } \\
\text { operation execution. }\end{array}$ & {$[75-77]$} \\
\hline 8. & $\begin{array}{l}\text { Flexible Power } \\
\text { Controller Method }\end{array}$ & $\begin{array}{l}\text { Manage the active and } \\
\text { reactive power } \\
\text { autonomously. Standard } \\
\text { adaptive current limiter to } \\
\text { approach the pre-placing } \\
\text { current obstacle. }\end{array}$ & $\begin{array}{l}\text { Steady voltage inside the } \\
\text { HMIDC operations by } \\
\text { means of the adjustable } \\
\text { power control at the } \\
\text { VSC-HVDC connection. }\end{array}$ & $\begin{array}{c}\text { No count of AC side } \\
\text { dynamics as well as load } \\
\text { effect. }\end{array}$ & {$[78,79]$} \\
\hline 9. & $\begin{array}{c}\text { Proportional } \\
\text { Integral Decoupled } \\
\text { Control }\end{array}$ & $\begin{array}{l}\text { Utilizes most effective } \\
\text { parameters in the PI } \\
\text { compensators within } \\
\text { several handle loops. }\end{array}$ & $\begin{array}{c}\text { Improves dynamic } \\
\text { performance significantly. }\end{array}$ & $\begin{array}{l}\text { Does not reflect the energy } \\
\text { failures of the transformer, } \\
\text { the grid filter, as well as } \\
\text { the converter. }\end{array}$ & {$[80,81]$} \\
\hline
\end{tabular}

\subsection{Dynamic Phasor Model of HVDC System}

The HVDC transmission power system is structured using the inverter, rectifier, and DC transmission line. The design of a single-pole HVDC system is depicted in Figure 10 [82]. The switching functions under switching OFF and switching ON describe the three forms of valves in HVDC converters. The time-domain representations of the rectifier of the HVDC operation are expressed in the following equations,

$$
\begin{gathered}
V_{m n}=V_{d r}=\left(V_{r a} S_{r v 1}+V_{r b} S_{r v 3}+V_{r c} S_{r v 5}\right)-\left(V_{r a} S_{r v 4}+V_{r b} S_{r v 6}+V_{r c} S_{r v 2}\right) \\
i_{r a}=i_{1}-i_{4}=i_{d} S_{r i 1}-i_{d} S_{r i 4} \\
i_{r b}=i_{3}-i_{6}=i_{d} S_{r i 3}-i_{d} S_{r i 6}
\end{gathered}
$$




$$
\begin{gathered}
i_{r c}=i_{5}-i_{2}=i_{d} S_{r i 5}-i_{d} S_{r i 2} \\
\left(2 L_{d}\right) \frac{d i_{d}}{d t}+r_{d} i_{d}=v_{d r}-v_{d i} \\
1 /{ }_{2}[\alpha+2 k \pi, \alpha+\gamma+2 k \pi] \\
1[\alpha+\delta+2 k \tau, \alpha+2 \pi 3+2 k \pi] \\
S_{v r 1}=\mid \begin{array}{c}
1 /{ }_{2}[\alpha+2 \pi 3+2 k \pi, \alpha+\gamma+2 \pi 3+2 k \pi] \\
0[\alpha+\gamma+2 \pi 3+2 k \pi, \alpha+2(k+1) \pi] \\
\theta-\alpha / \gamma \\
\left.S_{r i 1}=\mid \alpha+\alpha \pi, \alpha+\gamma+2 k \pi\right] \\
1[\alpha+\gamma+2 k \tau, \alpha+2 \pi 3+2 k \pi] \\
1-\frac{\theta-\alpha-2 \pi / 3}{\gamma}[\alpha+2 \pi 3+2 k \pi, \alpha+\gamma+2 \pi 3+2 k \pi] \\
0[\alpha+\gamma+2 \pi 3+2 k \pi, \alpha+2(k+1) \pi]
\end{array}
\end{gathered}
$$

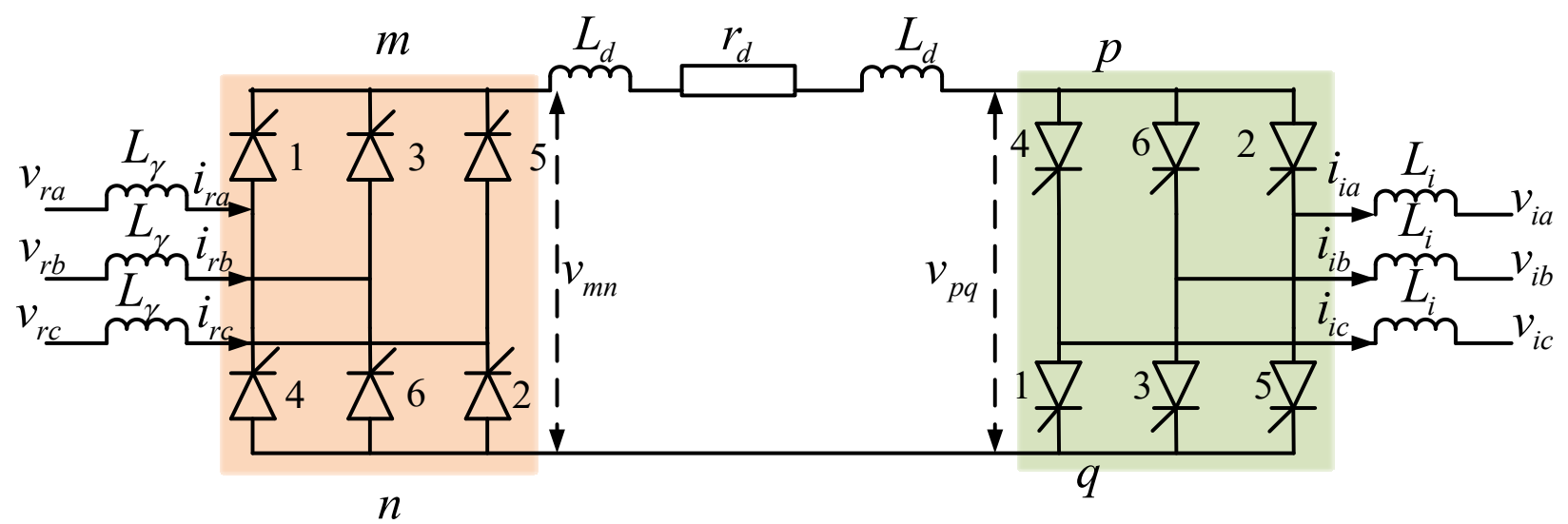

Figure 10. Dynamic phasor diagram of the HVDC system.

\section{Stability Assessment Models in HVDC}

The voltage regulation within the V-F control loop to improve the stability in the HVDC system is shown in Figure 11 [83]. A digital control of VSC-HVDC is employed to reduce the uncertainty of the potential oscillation without improving the advance of the basic material [84].

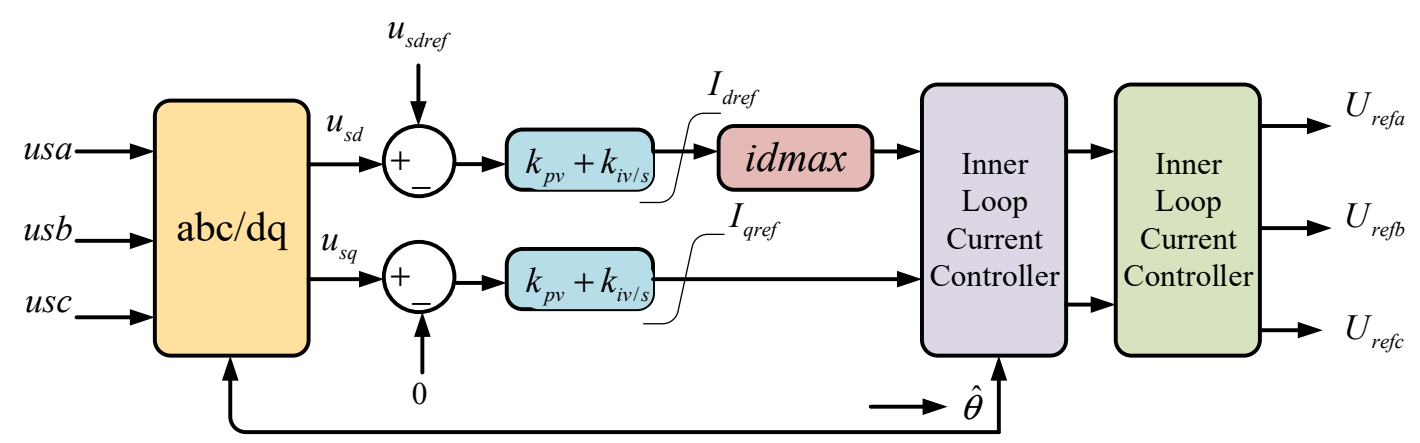

Figure 11. The voltage regulation in the V-F control loop.

The circulating current suppressor, PLL, and the current vector controller in the outside loop have substantial influences on the impedance feature within the low-frequency band. The improved proportional accretion $\mathrm{k}_{\mathrm{pv}}$ of the $\mathrm{AC}$ voltage regulator in the external loop decreases the impedance peak value of the VSC-HVDC operation, resulting in a reduction of the impedance peak value of the impedance ratio. 


\subsection{Control Strategies of MMC-MTDC}

Two control tasks are considered to control the VSC-MTDC systems properly and efficiently. The first one is the DC voltage control and the second one is the AC-side auxiliary control. DC voltage control is utilized to maintain the DC grid system. The DC voltage of the converter can balance the active power and manage the power flow in the DC networks $[85,86]$. The existing control strategies of the VSC-MTDC systems are suitable for MMC-MTDC operation.

(a) DC Voltage Control-the commonly used control architecture of a VSC in the MTDC systems is shown in Figure 12, which consists of inner and outer control loops [87]. This control scheme is also applicable to the MMC-based converter station. The DC voltage control is implemented through the outer control loop. Unlike the frequency of the AC system as a global control parameter, the DC voltage varies in the DC grid due to the power flow regulated among bus voltages of the DC network [88]. Currently, there are three primary methods for DC voltage control: Voltage margin control, master-slave control, and voltage droop control $[89,90]$.

(b) Power flow-the power flow and sharing of the VSC-MTDC systems is controlled by the DC voltage of each terminal, as shown in Figure 13 [87]. It is essential to consider the stability region, the limitation, and the optimal parameter determination of voltage control approaches to calculate the power flow and sharing. In [91], a powersharing control strategy and DC voltage are introduced based on a combination of an optimal DC power flow algorithm and a voltage-droop method for the most effective execution of the MTDC grids. Work by [73] proposes an improved analytic model for the steady-state analysis of droop-controlled VSC-MTDC operations. The authors in [92] suggested a generalized algorithm to solve the DC-power flow of the MTDC operations with various nonlinear voltage droops.

(c) Power Oscillation Damping-MTDC systems can also allow further control functions to develop system dynamic execution, such as transient stability and fault recovery [25], power oscillation damping [93], and sub-synchronous damping improvement [94]. The occurrence of low-frequency inter-area power oscillations is common in energy systems [95], which has resulted in some extensive-scale blackouts [96]. The inner-vicinity oscillation is one of the central causes of power system failure [97-99]. The damper windings of the synchronous machines, as well as digital electro-hydro structures without global signal computation, can reduce the innervicinity oscillations efficiently $[68,100]$. Thus, the attenuation of the inner-area power oscillations is important and has remained a challenge for a long time. Table 4 lists the details of some multi-terminal HVDC projects.

Table 4. Multi-terminal HVDC systems throughout the arena.

\begin{tabular}{cccccc}
\hline Systems Name & Terminal & Investing Year & $\begin{array}{c}\text { Estimated } \\
\text { Potential (MW) }\end{array}$ & $\begin{array}{c}\text { Estimated DC } \\
\text { Voltage (kV) }\end{array}$ & Converter Sample \\
\hline Quebec-New & 5 & $1990-1992,2016$ & $138 / 690 / 690 / 1,250 / 2$ & \pm 450 & LCC \\
England & 3 & 2015 & 800,2, & $\pm 0 / 100 / 200$ & MMC \\
Nan'ao & 5 & 2016 & $100 / 100 / 100 / 400 / 300$ & \pm 200 & MMC \\
Zhoushan & 4 & Under planning & 6000 & \pm 800 & LCC \\
North-East Agra & 4 & Under planning & $3000 / 3000 / 1500$ & \pm 500 & LCC \\
$\quad \begin{array}{l}\text { Zhangbei } \\
\text { Italy Corsica }\end{array}$ & 3 & $1967,1988,1992$ & $200 / 50 / 200$ & +200 & \\
Sardinia (SACOI) & & & & & \\
\hline
\end{tabular}




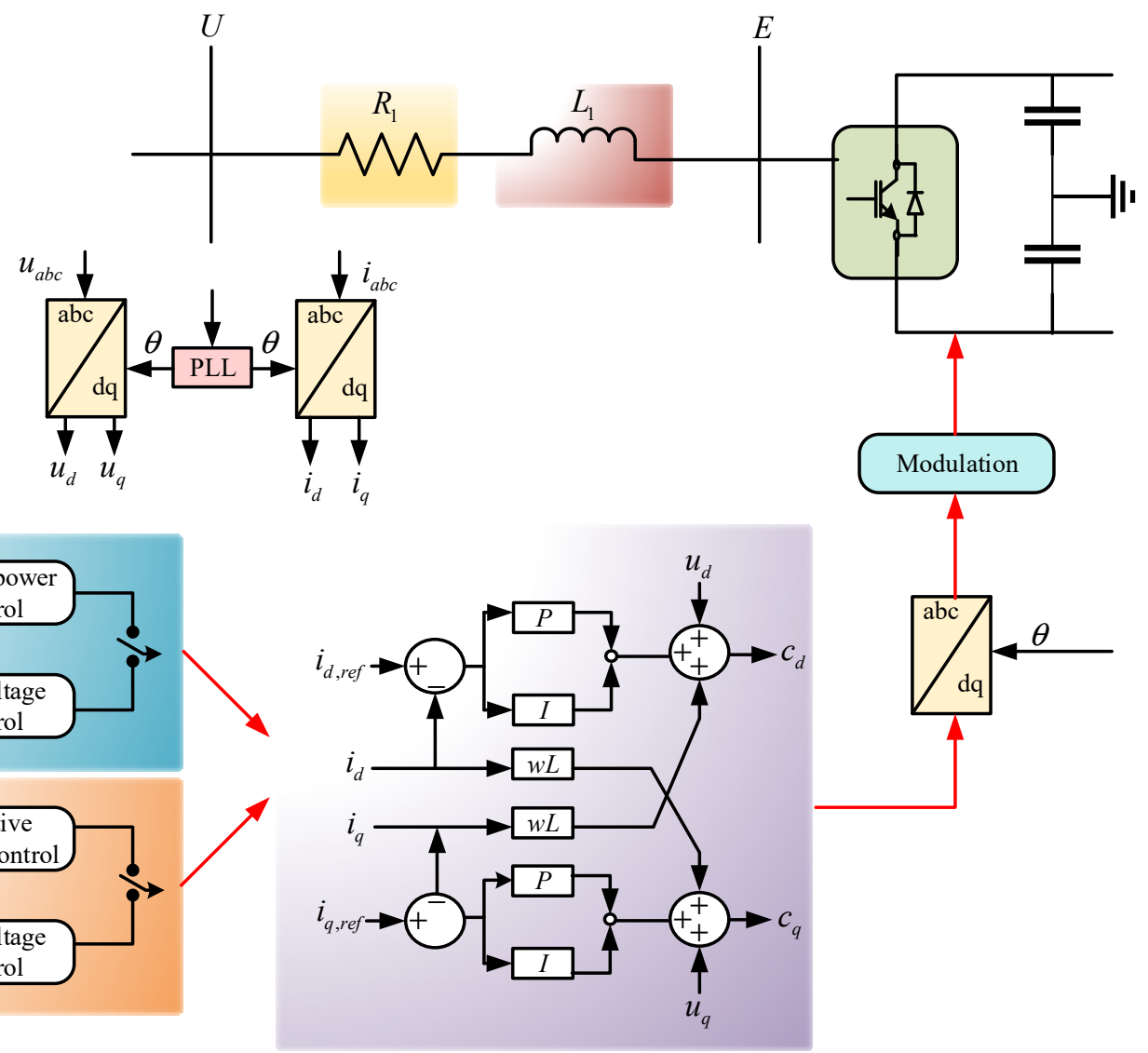

Figure 12. DC voltage and power control scheme of VSC.
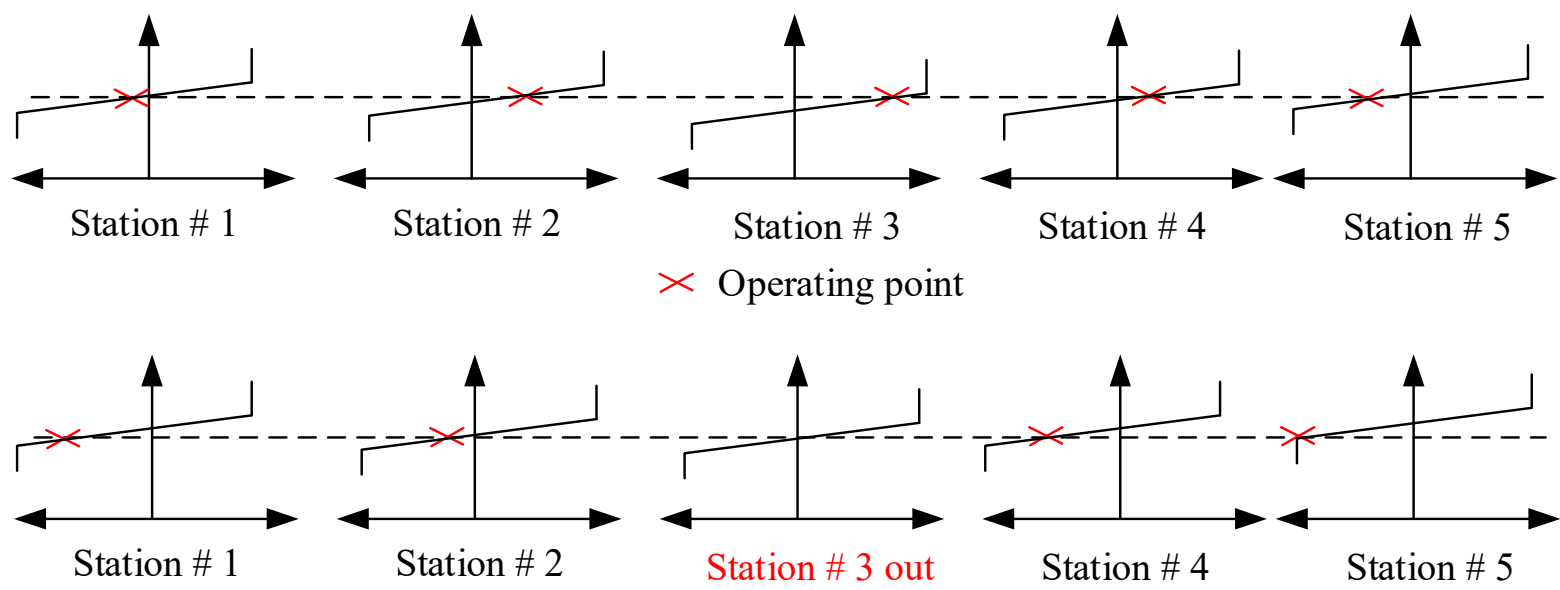

Figure 13. Characteristics of power sharing in a five-terminal MTDC system.

\subsection{Small Signal Stability}

The small-signal stability of the dynamic power system can be described properly through the utilization of the eigen analysis under the eigenvectors and eigenvalues of the system state matrix. The differential-algebraic equations (DAEs) of energy usage can be expressed as follows.

The small-signal stability of the dynamic power system can be described properly through the utilization of the eigen analysis under the eigenvectors and eigenvalues of the system state matrix. The differential-algebraic equations (DAEs) of energy usage can be expressed as follows:

$$
\dot{x}=f(x, y)
$$




$$
0=g(x, y)
$$

The state variables and algebraic variables are denoted by $x$ and $y$, respectively. The steady-state balance operation with the equilibrium factor is defined using the primary linearization as written in Equations in (22) and (23).

$$
\left[\begin{array}{c}
\Delta \dot{x} \\
0
\end{array}\right]=\left[\begin{array}{cc}
A & B \\
C & D
\end{array}\right]\left[\begin{array}{c}
\Delta X \\
\Delta Y
\end{array}\right]
$$

After excluding the algebraic variables, Equation (21) becomes

$$
\Delta \dot{x}=\left(A-B D^{-1} C\right) \Delta X=\widetilde{A}
$$

Equation (22) is the representation of the damping of the oscillatory forms, the frequency, and the actual eigenvalues resemble non-oscillatory methods. The proper eigenvector of a specific style provides the mode configuration, which gives the corresponding action of the state variables. If one of the eigenvalues has a positive real part, the method is unbalanced [101].

\subsection{Stability Improvement Models}

With the advancement of HVDC transmission technology, two or more HVDC systems can be fed into one AC side with the converters located nearby. Due to the diversification of the DC system control and operation, the difficulties of various multi-infeed HVDC systems are required to be investigated [102-105].

(1) Voltage Stability

For the investigation of voltage stability in the HVDC system, the slip of the dynamic load equivalent induction motor and the change ratio of the on-load tap switching transformer is required [85]. The voltage stability relationship ratio is shown in (23)

$$
\rho_{i}=\left|\begin{array}{c}
\sum P_{k i} \\
X_{k} \in(\Delta S, \Delta T) \\
\sum P_{k i} \\
X_{k} \notin(\Delta S, \Delta T)
\end{array}\right|
$$

where $T$ is the conversion ratio of the transformer and $s$ is the slip of the induction motor load.

The equipment of HVDC converter stations needs considerable measures of reactive power in the replacement process. In a typical situation, the specified reactive power on the rectifier side is $30-50 \%$ DC transmission power, in comparison to $40-60 \%$ on the inverter side. The voltage instability could take place due to the absence of reactive power, thus the HVDC system with vulnerable AC operation is one of the issues that can cause voltage instability [106-108]. The mathematical representation of the voltage stability correlation ratio (VSCR), without recognizing the dynamics of the on-load tap changer (OLTC), can be written as follows,

$$
\rho_{i}=\left|\begin{array}{c}
\sum P_{k i} \\
X_{k} \in(\Delta S, \Delta \alpha, \Delta \gamma) \\
\sum P_{k i} \\
X_{k} \notin(\Delta S, \Delta \alpha, \Delta \gamma)
\end{array}\right|
$$

where $\gamma$ denotes the extinction angle of an inverter and $\alpha$ presents the conduction angle of the rectifier.

In the real energy operation, if the eigenvalue $\lambda_{i}$ converges $\rho_{i}>1$, where the $\lambda_{i}$ has a meaningful relationship with voltage stability, then $P_{k i}$ is a means of the support of the state variable $X_{k}$ in the $i_{t h}$ voltage variation mode. The $P_{k i}$ by magnitude is a crucial component, which influences the voltage balance of the multi-infeed HVDC scheme.

(2) Harmonic Stability 
MMC energy frame is built primarily based on the harmonic linearization technique that is connected to the $A C$ link with sinusoidal voltage perturbation at frequency $f_{p}$ as displayed in Figure 14 [109].

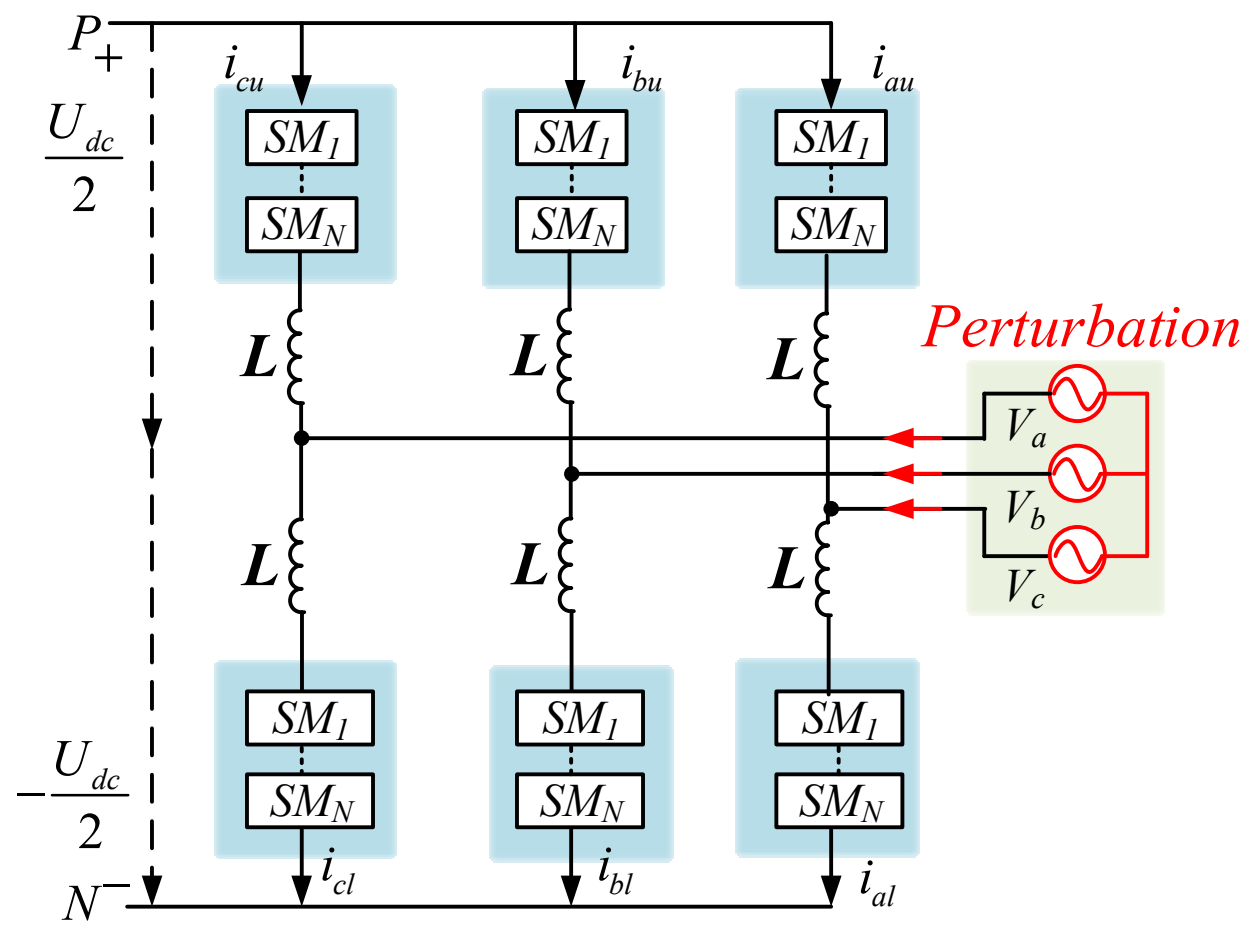

Figure 14. The configuration of MMC integrated with AC link voltage perturbation.

Here, phases are the voltage beside a meager voltage perturbation at frequency $f_{p}$ formulated as [110],

$$
v_{a}(t)=V_{a} \cos \left(2 \pi f_{1} t\right)+\hat{V}_{p} \cos \left(2 \pi f_{p} t+\varphi_{p}\right)
$$

The harmonic linearization approach is employed to obtain the converter impedance and exhibits numerous benefits, especially related to forming the dq-coordinate system. The steady-state operation trajectory can add the number of harmonics that it wants. The estimated impedance has visible versions and is instantly regulated [111] considering that the comparable switching frequency is large, while the capacitor voltages of submodules are always adjusted [112,113]. The small-signal design of the MMC energy level is achieved through the harmonic linearization using the higher arm of the phase [114].

$$
\begin{gathered}
Z_{1} \hat{l}_{a}=-\hat{v}_{p}-M_{a u} \hat{u}_{a u}-\hat{m}_{a u} u_{a u} \\
Y_{c} \hat{u}_{a u}=M_{a u} \hat{l}_{a u}+I_{a u} \hat{m}_{a u}
\end{gathered}
$$

The delivered voltage perturbation will head to a sequence of small-signal harmonic elements at frequency $f_{p} \pm k_{f 1}$, where $k=1,2 \ldots n$. Though it is hypothesized that the infinite harmonics are produced, the harmonics at $f_{p} \pm k_{f 1}$ will decrease drastically with the increment of $\mathrm{k}$. The third harmonics frequency in the MMC model $f_{1}$ is enough to examine the dynamic characteristics $[115,116]$. Accordingly, the harmonics up to $\mathrm{fp} \pm$ $3_{\mathrm{f} 1}$ are analyzed in all variables to adjust the precision of the model and the difficulty of the analytical performance. The small-signal harmonics elements such as frequency level, order, and functional mode under the negative-sequence and positive-sequence voltage perturbation integrated with the MMC AC link are presented in Table 5. 
Table 5. Small-signal harmonics elements including frequency, order, mode of operation, and voltage perturbation sequence.

\begin{tabular}{cccc}
\hline Frequency & Order & Mode & Voltage Sequence in MMC AC Link \\
\hline $\mathrm{f}_{\mathrm{p}}-3 \mathrm{f}_{1}$ & positive & Common Mode & \\
$\mathrm{f}_{\mathrm{p}}-2 \mathrm{f}_{1}$ & Negative & Differential Mode & Positive Sequence \\
$\mathrm{f}_{\mathrm{p}}-\mathrm{f}_{1}$ & zero & Common Mode & \\
$\mathrm{f}_{\mathrm{p}}$ & positive & Differential Mode & \\
$\mathrm{fp}+\mathrm{f} 1$ & Negative & Common Mode & \\
$\mathrm{fp}+2 \mathrm{f} 1$ & zero & Differential Mode & Negative Sequence \\
$\mathrm{fp}+3 \mathrm{f} 1$ & positive & Common Mode & \\
$\mathrm{f}_{\mathrm{p}}-3 \mathrm{f}_{1}$ & Negative & Common Mode & \\
$\mathrm{f}_{\mathrm{p}}-2 \mathrm{f}_{1}$ & zero & Differential Mode & \\
$\mathrm{f}_{\mathrm{p}}-\mathrm{f}_{1}$ & positive & Common Mode & \\
$\mathrm{f}_{\mathrm{p}}$ & Negative & Differential Mode & \\
$\mathrm{fp}+\mathrm{f} 1$ & zero & Common Mode & \\
$\mathrm{fp}+2 \mathrm{f} 1$ & positive & Differential Mode & \\
$\mathrm{fp}+3 \mathrm{f} 1$ & Negative & Common Mode & \\
\hline
\end{tabular}

(3) Current-Source System Stability

The voltage-supply operation durability hypothesizes that the reference is a voltage supply with constant voltage control within the open-circuit states without any load connected. Nevertheless, for grid-integrated inverters, they may usually be regulated to include specific current inside the grid, thus the voltage supply hypothesis will no longer be accurate. Accordingly, the current supply operation durability is introduced in [111] wherever the supply subsystem is presented as a current supply in correspondence with its output impedance. In Figure 15 [117], the current supply subsystem is presented as a current supply in correspondence with its output admittance Ys and the load is formed through its input admittance $Y_{1}$. The balance of such a system needs the admittance ratio $\mathrm{Y}_{\mathrm{S}} / \mathrm{Y}_{1}$ that meets the Nyquist stability criterion [111]. One utilization for such a balance criterion is grid-linked inverter structures, wherein the load impedance is substituted by a voltage supply in series within the grid impedance [118].

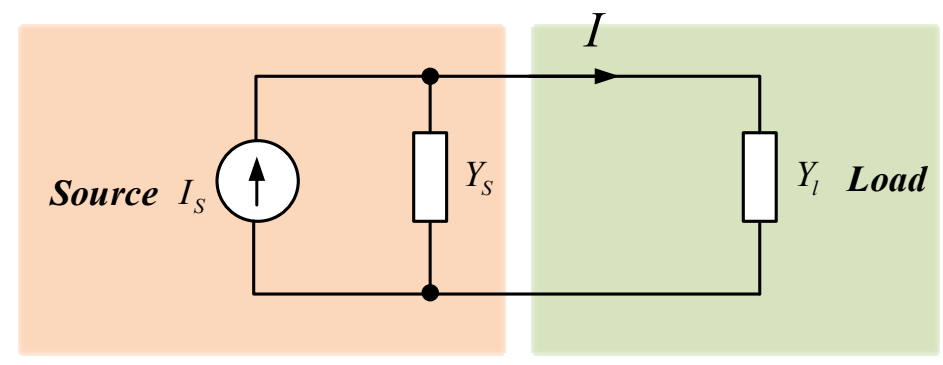

Figure 15. The presentation of the current-source system stability.

(4) HVDC Link Stability

The rectifiers and inverters control the current and voltage of the DC side under HVDC operations. Usually, the rectifier functions in the DC command mode and the inverter control operation in DC bus voltage are executed simultaneously. The traditional phasorbased state-space systems are accurate under the fundamental frequency that is utilized in the aforementioned impedance-primary-based stability study. The logical impedance standards are applied for the rectifier and inverter, as explained in [119]. The voltagesupply method stability evaluation might be utilized using the DC bus impedance and the rectifier output impedance.

(5) Steady-State Rotor Angle Stability

The reactive power compensators are installed at the mid-point of a lengthy transmission line to develop the power transfer capacity. The name transfer capacity here indicates the maximum power transfer among two AC systems, which is restrained by steady-state 
rotor angle stability. Figure 16 shows the simple two-machine system where the reactive power compensator is placed on the mid-point of the transmission line [120]. The voltage phasor at the sending end and the receiving end are assigned to be $V /(\delta / 2)$ and $V /(-\delta / 2)$, respectively.

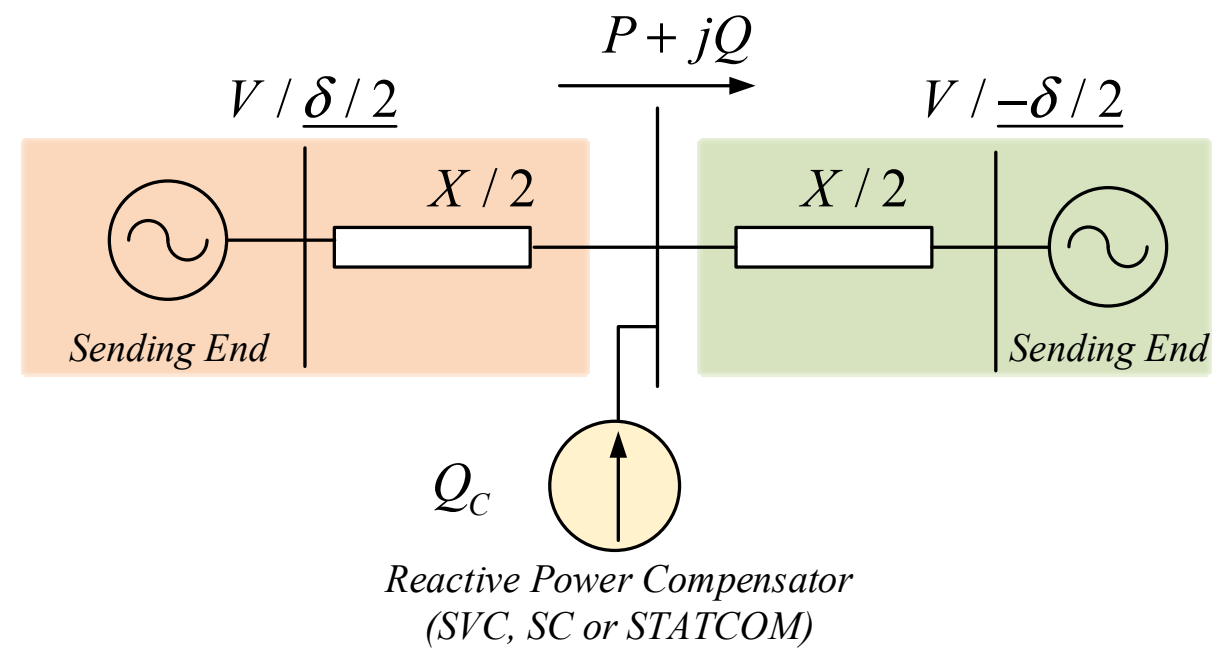

Figure 16. A two-machine system with mid-point compensation.

When there is no compensation, the power transfer is,

$$
P_{0}=\left(V^{2} / X\right) \sin \delta
$$

The maximum power transfer without compensation is,

$$
P_{\max 0}=\left(V^{2} / X\right)
$$

When a dynamic reactive compensator is installed, the mid-point voltage can be controlled and then the power flow on the transmission line becomes,

$$
P_{c}=\left(V^{2} / X\right) \sin (\delta / 2)
$$

The transfer limit discussed above is the background of a steady-state condition. Before the reactive power reaches the maximum value, the maximum power transfers are identical for all kinds of reactive power compensators, as shown in Equation (30). When the reactive power requirement exceeds the limit of the compensators, the mid-point voltage can no longer be maintained as a constant. The different compensators have different amounts of reactive power according to the reduced voltage. Therefore, the maximum power transfers will be different when different compensators are used.

\section{Issues and Challenges}

Although HVDC has received widespread attention in the power transmission system, various issues could hamper the grid operation including various faults, harmonics, reactive power, switching frequency, and voltage stability limitations. Moreover, the converter has some issues related to current and voltage stress and power dissipation. Furthermore, the choice of appropriate parameters in the controller is crucial because inappropriate parameters may lead to an imbalance that may influence operational performance and efficiency. Besides, many difficulties could happen whilst VSC-HVDC is integrated into a vulnerable AC system. Therefore, the abovementioned constraints need to be addressed in designing an effective model of the controller in the HVDC system. Some of the key issues and limitations of HVDC are outlined below. 
- When the obstruction in DC energy transfer takes place, reactive power consumption through the converter will fall to 0 . Therefore, the AC voltage might be developed because of the shunt capacitor and harmonic filter. These phenomena can demand excessive insulation of material within the operation, otherwise this material could probably be destroyed due to the overvoltage $[108,121]$.

- The direct current may be raised to revive the method to register energy. Therefore, the firing angle on the inverter may even improve to sustain the commutation edge. Reactive power by the inverter is improved by the shunt capacitor leading to a drop in AC voltage [122,123].

- Since harmonics are produced by the converter current at the AC link as well as the converter voltage at the DC link, harmonics generated through the DC side are enhanced whilst the DC energy release is improved [124]. Having said that, the energy transfer between AC and DC within the converter produces unusual harmonics although the pulse firing system is under control. It becomes a more serious issue when those unrepresentative harmonics damage the resonant networks, causing the operating status of the HV DC / AC operation to become complex $[125,126]$. The moderate harmonic resonance at the AC link would possibly generate further due to the DC link series resonance on the primary frequency, leading to critical difficulties $[127,128]$.

- Due to the switching among the shunt capacitor, the shunt reactor is rapidly under varying load conditions, and voltage variations may appear, which result in AC voltage flicker [129]. Moreover, voltage flicker takes place due to the inner harmonic generation through the change in loads. The influence of inner harmonics is more complex than harmonics. The inner harmonics frequencies are not integer multiples of the primary frequency, and the value of the voltage waveform would possibly swing even within the position of waveform distortions [130].

\section{Conclusions and Recommendations}

This review presents comprehensive information and analysis of HVDC modeling concentrating on the dynamic models, assessment models, control schemes, and limitations. As a first contribution, the review discusses the detailed insight into various HVDC models, emphasizing simplified modeling, the dynamic AVM, the VSC-based HVDC, the line-commutated converter, and the dynamic phasor model. The types, configurations, mathematical representation, computing times, simulation, and various tools are highlighted. As a second contribution, this review narrates the different HVDC assessment models focusing on stability analysis, HVDC link stability, and steady-state rotor angle stability. The voltage stability, harmonic stability, and current-source system under stability improvement models are also discussed. As a third contribution, the control strategies of LCC-HVDC and MMC-MTDC are explored denoting operations, benefits, and shortcomings. As a fourth contribution, the key issues and problems that are identified related to the inverter, reactive power, harmonics, switching, and frequency are discussed. As the fifth contribution, this review proposes some recommendations for the advancement of HDC modeling, as follows:

- $\quad$ The VSC-HVDC has synchronization issues while connected to a vulnerable AC system. Aside from interfacing with a limited AC operation, the VSC-HVDC-based adaptive backstepping controller is applied to handle voltage droop in the offshore wind farm. The adaptive back-stepping controller is employed to decrease the voltage rise as well as the minimal voltage drop at some point of a fault situation, leading to an improvement in voltage output with the diminished settling period. To address the aforesaid concerns, a PI controller and a fuzzy controller can be employed to stabilize the network operation.

- The selection of appropriate controller parameters is crucial to enhance the stability performance of the VSC-HVDC transmission system. Hence, the different optimization algorithms can be integrated with controllers such as PI and fuzzy logic. Nevertheless, 
the inclusion of optimization may increase the installation cost as well as commutation loss. Since the operation of VSC is constrained under limited voltage and power levels, further studies are required on VSC-HVDC under different levels of voltage and power.

- The very specific DC operations still pose various severe restrictions to the scope of the network. Thus, the advancement of hybrid models can be suggested including a complete EMT design of the DC operation and the AC operation within the era of the converter, connected to a preferred electromechanical version for the remainder of the AC system. Such connected methods are in a situation of continuous study and will operate an influential part of incoming energy system modeling for dynamic AC/DC operation.

- $\quad$ For large-scale power systems, further effective models need to be improved with active simulation acceleration. Nevertheless, the models are required to simulate state variables correctly with a small-time step under dynamic responses leading to a high computational load. Consequently, there is a tradeoff between precision and effectiveness. The future control strategy of the MMC-MTDC systems can be developed using droop control to improve the performance in both AC and DC structures by addressing the converter outages and power oscillations. Multi-functional control configurations could assure an effective control plan of the MMC-MTDC systems.

- The abovementioned recommendations could play remarkable roles in developing and executing advanced HVDC models. Moreover, the information and analysis of this review can deliver a clear idea and information to power system engineers and researchers on the HVDC model structure, assessment models, and control schemes. Overall, this review helps to pave a pathway for future sustainable power transmission systems.

Author Contributions: Conceptualization, T.A. and M.A.H.; methodology, M.S.H.L.; software, S.A.R.; validation, P.J.K., C.T.Y. and K.M.M.; formal analysis, M.S.H.L.; investigation, T.A.; resources, P.J.K.; data curation, S.A.R.; writing-original draft preparation, T.A.; writing-M.S.H.L. and M.A.H.; visualization, S.K.T. and K.M.M.; supervision, M.A.H.; project administration, S.K.T.; funding acquisition, M.A.H. All authors have read and agreed to the published version of the manuscript.

Funding: The authors are thankful for the financial support provided by University Tenaga Nasional under grant no 20190101LRGS and in part by the UNITEN Bold Refresh Publication Fund 2021, under Project J5100D4103.

Conflicts of Interest: The authors declare no conflict of interest.

\section{References}

1. Hannan, M.A.; Hussin, I.; Ker, P.J.; Hoque, M.M.; Hossain Lipu, M.S.; Hussain, A.; Rahman, M.S.A.; Faizal, C.W.M.; Blaabjerg, F. Advanced control strategies of VSC Based HVDC transmission system: Issues and potential recommendations. IEEE Access 2018, 6, 78352-78369. [CrossRef]

2. Alassi, A.; Bañales, S.; Ellabban, O.; Adam, G.; MacIver, C. HVDC Transmission: Technology Review, Market Trends and Future Outlook. Renew. Sustain. Energy Rev. 2019, 112, 530-554. [CrossRef]

3. Pierri, E.; Binder, O.; Hemdan, N.G.A.; Kurrat, M. Challenges and opportunities for a European HVDC grid. Renew. Sustain. Energy Rev. 2017, 70, 427-456. [CrossRef]

4. Benasla, M.; Allaoui, T.; Brahami, M.; Denaï, M.; Sood, V.K. HVDC links between North Africa and Europe: Impacts and benefits on the dynamic performance of the European system. Renew. Sustain. Energy Rev. 2018, 82, 3981-3991. [CrossRef]

5. Tosatto, A.; Weckesser, T.; Chatzivasileiadis, S. Market Integration of HVDC Lines: Internalizing HVDC Losses in Market Clearing. IEEE Trans. Power Syst. 2020, 35, 451-461. [CrossRef]

6. Xiao, H.; Sun, K.; Pan, J.; Li, Y.; Liu, Y. Review of hybrid HVDC systems combining line communicated converter and voltage source converter. Int. J. Electr. Power Energy Syst. 2021, 129, 106713. [CrossRef]

7. Semeraro, M.A. Renewable energy transport via hydrogen pipelines and HVDC transmission lines. Energy Strategy Rev. 2021, 35, 100658. [CrossRef]

8. Khazaei, J.; Idowu, P.; Asrari, A.; Shafaye, A.; Piyasinghe, L. Review of HVDC control in weak AC grids. Electr. Power Syst. Res. 2018, 162, 194-206. [CrossRef] 
9. Kamari, N.A.M.; Musirin, I.; Ibrahim, A.A.; Halim, S.A. Intelligent swarm-based optimization technique for oscillatory stability assessment in power system. IAES Int. J. Artif. Intell. 2019, 8, 342-351. [CrossRef]

10. Briff, P.; Chivite-Zabalza, J.; Nicholls, J.; Vershinin, K. Turn-Off Delay Compensation of Series-Connected IGBTs for HVDC Applications. IEEE Trans. Power Electron. 2020, 35, 11294-11298. [CrossRef]

11. Islam, N.N.; Hannan, M.A.; Shareef, H.; Mohamed, A. An application of backtracking search algorithm in designing power system stabilizers for large multi-machine system. Neurocomputing 2017, 237, 175-184. [CrossRef]

12. Li, R.; Yu, L.; Xu, L.; Adam, G.P. Coordinated Control of Parallel DR-HVDC and MMC-HVDC Systems for Offshore Wind Energy Transmission. IEEE J. Emerg. Sel. Top. Power Electron. 2020, 8, 2572-2582. [CrossRef]

13. Sun, P.; Wickramasinghe, H.R.; Konstantinou, G. Hybrid LCC-AAC HVDC transmission system. Electr. Power Syst. Res. 2021, 192, 106910. [CrossRef]

14. Haleem, N.M.; Rajapakse, A.D.; Gole, A.M.; Fernando, I.T. Investigation of Fault Ride-Through Capability of Hybrid VSC-LCC Multi-Terminal HVDC Transmission Systems. IEEE Trans. Power Deliv. 2019, 34, 241-250. [CrossRef]

15. Silva, K.M.; Tavares, J.J.C.; Ribeiro, N.S.S.; Lopes, F.V. Impact of DFT-Based phasor estimation errors due to commutation failures of LCC-HVDC links on the protection of AC lines in the near vicinity. Electr. Power Syst. Res. 2021, 196, 107287. [CrossRef]

16. Song, J.; Li, Y.; Zhang, Y. Fault steady-state analysis method for the AC system with LCC-HVDC infeed. Electr. Power Syst. Res. 2021, 192, 106994. [CrossRef]

17. Raza, A.; Yousaf, Z.; Jamil, M.; Gilani, S.O.; Abbas, G.; Uzair, M.; Shaheen, S.; Benrabah, A.; Li, F. Multi-Objective Optimization of VSC Stations in Multi-Terminal VSC-HVdc Grids, Based on PSO. IEEE Access 2018, 6, 62995-63004. [CrossRef]

18. Adewolu, B.O.; Saha, A.K. Contingency Control Capability of an Optimized HVDC-based VSC Transmission System. IEEE Access 2020, 9, 4112-4128. [CrossRef]

19. Guo, C.; Zhao, C.; Iravani, R.; Ding, H.; Wang, X. Impact of phase-locked loop on small-signal dynamics of the line commutated converter-based high-voltage direct-current station. IET Gener. Transm. Distrib. 2017, 11, 1311-1318. [CrossRef]

20. Zou, C.; Rao, H.; Xu, S.; Li, Y.; Li, W.; Chen, J.; Zhao, X.; Yang, Y.; Lei, B. Analysis of Resonance between a VSC-HVDC Converter and the AC Grid. IEEE Trans. Power Electron. 2018, 33, 10157-10168. [CrossRef]

21. Wang, Y.; Zhao, C.; Guo, C. Comparison study of small-signal stability of MMC-HVDC system in different control modes. Int. J. Electr. Power Energy Syst. 2019, 111, 425-435. [CrossRef]

22. Daryabak, M.; Filizadeh, S.; Jatskevich, J.; Davoudi, A.; Saeedifard, M.; Sood, V.K.; Martinez, J.A.; Aliprantis, D.; Cano, J.; Mehrizi-Sani, A. Modeling of LCC-HVDC systems using dynamic phasors. IEEE Trans. Power Deliv. 2014, 29, 1989-1998. [CrossRef]

23. Annakkage, U.D.; Karawita, C.; Arunprasanth, S.; Konara, H. Dynamic phasor modeling of HVDC systems. In Modeling and Simulation of HVDC Transmission; Institution of Engineering and Technology (IET): London, UK, 2020; pp. $213-243$.

24. Debnath, S.; Qin, J.; Bahrani, B.; Saeedifard, M.; Barbosa, P. Operation, control, and applications of the modular multilevel converter: A review. IEEE Trans. Power Electron. 2015, 30, 37-53. [CrossRef]

25. Liu, L.; Liu, C. VSCs-HVDC may improve the Electrical Grid Architecture in future world. Renew. Sustain. Energy Rev. 2016, 62, 1162-1170. [CrossRef]

26. Hong, L.; Zhou, X.; Xia, H.; Liu, Y.; Luo, A. Mechanism and prevention of commutation failure in LCC-HVDC caused by sending end AC faults. IEEE Trans. Power Deliv. 2021, 36, 473-476. [CrossRef]

27. Xiao, H.; Li, Y.; Lan, T. Sending End AC Faults can Cause Commutation Failure in LCC-HVDC Inverters. IEEE Trans. Power Deliv. 2020, 35, 2554-2557. [CrossRef]

28. Xue, Y.; Zhang, X.-P.; Yang, C. Commutation Failure Elimination of LCC HVDC Systems Using Thyristor-Based Controllable Capacitors. IEEE Trans. Power Deliv. 2018, 33, 1448-1458. [CrossRef]

29. Xue, Y.; Zhang, X.-P.; Yang, C. AC Filterless Flexible LCC HVDC With Reduced Voltage Rating of Controllable Capacitors. IEEE Trans. Power Syst. 2018, 33, 5507-5518. [CrossRef]

30. Mitra, P.; Zhang, L.; Harnefors, L. Offshore Wind Integration to a Weak Grid by VSC-HVDC Links Using Power-Synchronization Control: A Case Study. IEEE Trans. Power Deliv. 2014, 29, 453-461. [CrossRef]

31. Huang, L.; Xin, H.; Yang, H.; Wang, Z.; Xie, H. Interconnecting Very Weak AC Systems by Multiterminal VSC-HVDC Links with a Unified Virtual Synchronous Control. IEEE J. Emerg. Sel. Top. Power Electron. 2018, 6, 1041-1053. [CrossRef]

32. Ndreko, M.; Rueda, J.L.; Popov, M.; van der Meijden, M.A.M.M. Optimal fault ride through compliance of offshore wind power plants with VSC-HVDC connection by meta-heuristic based tuning. Electr. Power Syst. Res. 2017, 145, 99-111. [CrossRef]

33. Cigré, W.G. Guide for the Development of Models for HVDC Converters in a HVDC Grid; CIGRE: Paris, France, 2014; ISBN 9782858733057.

34. Antonopoulos, A.; Angquist, L.; Nee, H.-P. On dynamics and voltage control of the Modular Multilevel Converter. In Proceedings of the 13th European Conference on Power Electronics and Applications, Barcelona, Spain, 8-10 September 2009; pp. 1-5.

35. Jacobson, B.; Karlsson, P.; Asplund, G.; Harnefors, L.; Jonsson, T. VSC-HVDC Transmission with Cascaded Two-Level Converters. In Proceedings of the CIGRE Technical Exhibition: The Prestigious Event in the World of HV, Paris, France, 22-27 August 2010; B4-110. pp. 1-8.

36. De Toledo Silva, F.A.; Komatsu, W.; Jardini, J.A. Use of DC/DC converters modeled as AC-DC converters in HVDC Grids. In Proceedings of the IEEE PES Transmission and Distribution Conference and Exhibition, Montevideo, Uruguay, 28 September2 October 2020; pp. 1-6. 
37. Peralta, J.; Saad, H.; Dennetière, S.; Mahseredjian, J.; Nguefeu, S. Detailed and averaged models for a 401-level MMC-HVDC system. IEEE Trans. Power Deliv. 2012, 27, 1501-1508. [CrossRef]

38. Oleka, E.U.; Ndubisi, S.N.; Ijemaru, G.K. Electric Power Transmission Enhancement: A Case of Nigerian Electric Power Grid. Am. J. Electr. Electron. Eng. 2016, 4, 33-39.

39. Sood, V.K. HVDC and FACTS Controllers-Applications of Static Converters in Power Systems; Springer: Cham, Switzerland, 2004.

40. Eremia, M.; Liu, C.C.; Edris, A.A. Advanced Solutions in Power Systems: HVDC, FACTS, and AI Techniques; Wiley-IEEE Press: Piscataway, NJ, USA, 2016; ISBN 9781119175391.

41. Karaolanis, A.; Perilla Guerra, A.; Rueda Torres, J.L.; van der Meijden, M.A.A.M.; Alefragkis, A. Generic model of a VSC-based HVDC link for RMS simulations in PSS/E. IFAC-PapersOnLine 2018, 51, 303-308. [CrossRef]

42. Dragan, J. High Voltage Direct Current Transmission: Converters, Systems and DC Grids; Wiley: Piscataway, NJ, USA, 2015.

43. Wang, D.; Fu, J.; Hou, M.; Qiao, F.; Gao, M. Novel travelling wave fault location principle for VSC-HVDC transmission line. Electr. Power Syst. Res. 2021, 196, 107226. [CrossRef]

44. Li, C.; Cao, Y.; Yang, Y.; Wang, L.; Blaabjerg, F.; Dragicevic, T. Impedance-based method for DC stability of VSC-HVDC system with VSG control. Int. J. Electr. Power Energy Syst. 2021, 130, 106975. [CrossRef]

45. Li, B.; Wang, W.; Liu, Y.; Li, B.; Wen, W. Research on power flow calculation method of true bipolar VSC-HVDC grids with different operation modes and control strategies. Int. J. Electr. Power Energy Syst. 2021, 126, 106558. [CrossRef]

46. Li, B.; Mao, Q.; He, J.; Li, Y.; Wu, T.; Dai, W.; Li, X.; Yu, Q. Adaptive reclosing strategy for the mechanical DC circuit breaker in VSC-HVDC grid. Electr. Power Syst. Res. 2021, 192, 107008. [CrossRef]

47. Sima, W.; Fu, Z.; Yang, M.; Yuan, T.; Sun, P.; Han, X.; Si, Y. A Novel Active Mechanical HVDC Breaker with Consecutive Interruption Capability for Fault Clearances in MMC-HVDC Systems. IEEE Trans. Ind. Electron. 2019, 66, 6979-6989. [CrossRef]

48. Man, J.; Xie, X.; Xu, S.; Zou, C.; Yin, C. Frequency-Coupling Impedance Model Based Analysis of a High-Frequency Resonance Incident in an Actual MMC-HVDC System. IEEE Trans. Power Deliv. 2020, 35, 2963-2971. [CrossRef]

49. Harnefors, L.; Finger, R.; Wang, X.; Bai, H.; Blaabjerg, F. VSC Input-Admittance Modeling and Analysis above the Nyquist Frequency for Passivity-Based Stability Assessment. IEEE Trans. Ind. Electron. 2017, 64, 6362-6370. [CrossRef]

50. Shinoda, K.; Benchaib, A.; Dai, J.; Guillaud, X. DC voltage control of MMC-based HVDC grid with Virtual Capacitor Control. In Proceedings of the European Conference on Power Electronics and Applications, Warsaw, Poland, 11-14 September 2017; pp. $1-10$.

51. Atighechi, H.; Chiniforoosh, S.; Jatskevich, J.; Davoudi, A.; Martinez, J.A.; Faruque, M.O.; Sood, V.; Saeedifard, M.; Cano, J.M.; Mahseredjian, J.; et al. Dynamic average-value modeling of CIGRE HVDC benchmark system. IEEE Trans. Power Deliv. 2014, 29, 2046-2054. [CrossRef]

52. Pegueroles, J.; Barnes, M.; Gomis, O.; Beddard, A.; Bianchi, F.D. Modelling and analysis of CIGRE HVDC offshore multi-terminal benchmark grid. Energy Procedia 2015, 80, 72-82. [CrossRef]

53. Beddard, A.; Barnes, M. Modelling of MMC-HVDC systems-An overview. Energy Procedia 2015, 80, 201-212. [CrossRef]

54. Beddard, A.; Barnes, M.; Preece, R. Comparison of Detailed Modeling Techniques for MMC Employed on VSC-HVDC Schemes. IEEE Trans. Power Deliv. 2015, 30, 579-589. [CrossRef]

55. Zhang, L.; Harnefors, L.; Nee, H.P. Modeling and control of VSC-HVDC links connected to island systems. IEEE Trans. Power Syst. 2011, 26, 783-793. [CrossRef]

56. Xu, T.; Donoghue, M.W.; Davidson, C.C. IGBT overcurrent turn-off tests for the MMC-based VSC valves. In Proceedings of the European Conference on Power Electronics and Applications, Lille, France, 2-6 September 2013; pp. 1-6.

57. Saad, H.; Peralta, J.; Dennetiere, S.; Mahseredjian, J.; Jatskevich, J.; Martinez, J.A.; Davoudi, A.; Saeedifard, M.; Sood, V.; Wang, X.; et al. Dynamic Averaged and Simplified Models for MMC-Based HVDC Transmission Systems. IEEE Trans. Power Deliv. 2013, 28, 1723-1730. [CrossRef]

58. Gnanarathna, U.N.; Gole, A.M.; Jayasinghe, R.P. Efficient modeling of modular multilevel HVDC converters (MMC) on electromagnetic transient simulation programs. IEEE Trans. Power Deliv. 2011, 26, 316-324. [CrossRef]

59. Khan, S.; Bhowmick, S. A novel power-flow model of multi-terminal VSC-HVDC systems. Electr. Power Syst. Res. 2016, 133, 219-227. [CrossRef]

60. Khan, S.; Bhowmick, S. Generalized power flow models for VSC based multi-terminal HVDC systems. Int. J. Electr. Power Energy Syst. 2016, 82, 67-75. [CrossRef]

61. Filizadeh, S.; Gole, A.M.; Woodford, D.A.; Irwin, G.D. An optimization-enabled electromagnetic transient simulation-based methodology for HVDC controller design. IEEE Trans. Power Deliv. 2007, 22, 2559-2566. [CrossRef]

62. Niamul Islam, N.; Hannan, M.A.; Mohamed, A.; Shareef, H. Improved Power System Stability Using Backtracking Search Algorithm for Coordination Design of PSS and TCSC Damping Controller. PLoS ONE 2016, 11, e0146277. [CrossRef]

63. Luo, S.; Dong, X.; Shi, S.; Wang, B. A Directional Protection Scheme for HVDC Transmission Lines Based on Reactive Energy. IEEE Trans. Power Deliv. 2016, 31, 559-567. [CrossRef]

64. Li, Y.; Luo, L.; Rehtanz, C.; Rüberg, S.; Liu, F. Realization of Reactive Power Compensation Near the LCC-HVDC Converter Bridges by Means of an Inductive Filtering Method. IEEE Trans. Power Electron. 2012, 27, 3908-3923. [CrossRef]

65. Pradhan, J.K.; Ghosh, A.; Bhende, C.N. Small-signal modeling and multivariable PI control design of VSC-HVDC transmission link. Electr. Power Syst. Res. 2017, 144, 115-126. [CrossRef] 
66. Harnefors, L.; Wang, X.; Yepes, A.G.; Blaabjerg, F. Passivity-based stability assessment of grid-connected VSCs-An overview. IEEE J. Emerg. Sel. Top. Power Electron. 2015, 4, 116-125. [CrossRef]

67. Guo, C.; Liu, W.; Zhao, C.; Iravani, R. A Frequency-Based Synchronization Approach for the VSC-HVDC Station Connected to a Weak AC Grid. IEEE Trans. Power Deliv. 2017, 32, 1460-1470. [CrossRef]

68. Hannan, M.A.; Islam, N.N.; Mohamed, A.; Lipu, M.S.H.; Ker, P.J.; Rashid, M.M.; Shareef, H. Artificial Intelligent Based Damping Controller Optimization for the Multi-Machine Power System: A Review. IEEE Access 2018, 6, 39574-39594. [CrossRef]

69. Nanou, S.I.; Papathanassiou, S.A. Grid Code Compatibility of VSC-HVDC Connected Offshore Wind Turbines Employing Power Synchronization Control. IEEE Trans. Power Syst. 2016, 31, 5042-5050. [CrossRef]

70. Zhang, L.; Harnefors, L.; Nee, H.-P. Power-Synchronization Control of Grid-Connected Voltage-Source Converters. IEEE Trans. Power Syst. 2010, 25, 809-820. [CrossRef]

71. Bergna, G.; Garces, A.; Berne, E.; Egrot, P.; Arzande, A.; Vannier, J.C.; Molinas, M. A generalized power control approach in ABC frame for modular multilevel converter HVDC links based on mathematical optimization. IEEE Trans. Power Deliv. 2014, 29, 386-394. [CrossRef]

72. Xiang, W.; Lin, W.; An, T.; Wen, J.; Wu, Y. Equivalent Electromagnetic Transient Simulation Model and Fast Recovery Control of Overhead VSC-HVDC Based on SB-MMC. IEEE Trans. Power Deliv. 2017, 32, 778-788. [CrossRef]

73. Xiao, L.; Xu, Z.; An, T.; Bian, Z. Improved Analytical Model for the Study of Steady State Performance of Droop-Controlled VSC-MTDC Systems. IEEE Trans. Power Syst. 2017, 32, 2083-2093. [CrossRef]

74. Prieto-Araujo, E.; Bianchi, F.D.; Junyent-Ferre, A.; Gomis-Bellmunt, O. Methodology for Droop Control Dynamic Analysis of Multiterminal VSC-HVDC Grids for Offshore Wind Farms. IEEE Trans. Power Deliv. 2011, 26, 2476-2485. [CrossRef]

75. Mahela, O.P.; Shaik, A.G. Comprehensive overview of grid interfaced wind energy generation systems. Renew. Sustain. Energy Rev. 2016, 57, 260-281. [CrossRef]

76. Lee, C.H.; Chung, B.R. Adaptive backstepping controller design for nonlinear uncertain systems using fuzzy neural systems. Int. J. Syst. Sci. 2012, 43, 1855-1869. [CrossRef]

77. Huang, J.; Xu, D.; Yan, W.; Ge, L.; Yuan, X. Nonlinear Control of Back-to-Back VSC-HVDC System via Command-Filter Backstepping. J. Control Sci. Eng. 2017, 2017, 1-10. [CrossRef]

78. Liu, Y.; Chen, Z. A Flexible Power Control Method of VSC-HVDC Link for the Enhancement of Effective Short-Circuit Ratio in a Hybrid Multi-Infeed HVDC System. IEEE Trans. Power Syst. 2013, 28, 1568-1581. [CrossRef]

79. Mc Namara, P.; Negenborn, R.R.; De Schutter, B.; Lightbody, G. Optimal Coordination of a Multiple HVDC Link System Using Centralized and Distributed Control. IEEE Trans. Control Syst. Technol. 2013, 21, 302-314. [CrossRef]

80. Liu, J.; Tai, N.; Fan, C. Transient-Voltage-Based Protection Scheme for DC Line Faults in the Multiterminal VSC-HVDC System. IEEE Trans. Power Deliv. 2017, 32, 1483-1494. [CrossRef]

81. Schönleber, K.; Collados, C.; Pinto, R.T.; Ratés-Palau, S.; Gomis-Bellmunt, O. Optimization-based reactive power control in HVDC-connected wind power plants. Renew. Energy 2017, 109, 500-509. [CrossRef]

82. Hannan, M.A.; Lipu, M.S.H.; Ker, P.J.; Begum, R.A.; Agelidis, V.G.; Blaabjerg, F. Power electronics contribution to renewable energy conversion addressing emission reduction: Applications, issues, and recommendations. Appl. Energy 2019, $251,113404$. [CrossRef]

83. Guo, M.; Li, X.; Gao, Z.; Su, G. Simulation and Analysis on Stability Improvement of Zhangbei Renewable Energy Transmission via VSC-HVDC Based on RTDS. In Proceedings of the International Conference on HVDC, Xi'an, China, 6-9 November 2020; pp. 299-303.

84. System, M.; Wang, Y.; Zhao, C.; Member, S.; Guo, C.; Member, S.; Rehman, A.U. Dynamic modeling and small signal stability analysis of PMSG-based wind farm with MMC-HVDC system. CSEE J. Power Energy Syst. 2019, 6, $226-235$.

85. Gavriluta, C.; Candela, J.I.; Rocabert, J.; Luna, A.; Rodriguez, P. Adaptive droop for control of multiterminal DC bus integrating energy storage. IEEE Trans. Power Deliv. 2015, 30, 16-24. [CrossRef]

86. Gavriluta, C.; Candela, I.; Luna, A.; Gomez-Exposito, A.; Rodriguez, P. Hierarchical Control of HV-MTDC Systems With Droop-Based Primary and OPF-Based Secondary. IEEE Trans. Smart Grid 2015, 6, 1502-1510. [CrossRef]

87. Zhang, L.; Zou, Y.; Yu, J.; Qin, J.; Vijay, V.; Karady, G.G.; Shi, D.; Wang, Z. Modeling, control, and protection of modular multilevel converter-based multi-terminal HVDC systems: A review. CSEE J. Power Energy Syst. 2017, 3, 340-352. [CrossRef]

88. Rouzbehi, K.; Miranian, A.; Candela, J.I.; Luna, A.; Rodriguez, P. A generalized voltage droop strategy for control of multiterminal DC grids. IEEE Trans. Ind. Appl. 2015, 51, 607-618. [CrossRef]

89. Chen, X.; Wang, L.; Sun, H.; Chen, Y. Fuzzy Logic Based Adaptive Droop Control in Multiterminal HVDC for Wind Power Integration. IEEE Trans. Energy Convers. 2017, 32, 1200-1208. [CrossRef]

90. Haileselassie, T.M.; Uhlen, K. Impact of DC line voltage drops on power flow of MTDC using droop control. IEEE Trans. Power Syst. 2012, 27, 1441-1449. [CrossRef]

91. Rouzbehi, K.; Miranian, A.; Luna, A.; Rodriguez, P. DC voltage control and power sharing in multiterminal DC grids based on optimal DC power flow and voltage-droop strategy. IEEE J. Emerg. Sel. Top. Power Electron. 2014, 2, 1171-1180. [CrossRef]

92. Wang, W.; Barnes, M. Power flow algorithms for multi-terminal VSC-HVDC with droop control. IEEE Trans. Power Syst. 2014, 29, 1721-1730. [CrossRef]

93. Vural, A.M. Contribution of high voltage direct current transmission systems to inter-area oscillation damping: A review. Renew. Sustain. Energy Rev. 2016, 57, 892-915. [CrossRef] 
94. Xu, Y.; Bai, W.; Zhao, S.; Zhang, J.; Zhao, Y. Mitigation of forced oscillations using VSC-HVDC supplementary damping control. Electr. Power Syst. Res. 2020, 184, 106333. [CrossRef]

95. Preece, R.; Milanović, J.V. Power Oscillation Damping using VSC-based Multi-terminal HVDC grids. IFAC Proc. Vol. 2012, 45, 20-25. [CrossRef]

96. Alhelou, H.H.; Hamedani-Golshan, M.E.; Njenda, T.C.; Siano, P. A survey on power system blackout and cascading events: Research motivations and challenges. Energies 2019, 12, 682. [CrossRef]

97. Yin, C.; Xie, X.; Xu, S.; Zou, C. Review of oscillations in VSC-HVDC systems caused by control interactions. J. Eng. 2019, 2019, 1204-1207. [CrossRef]

98. Wang, Y.; Zhou, Y.; Li, D.; Shao, D.; Cao, K.; Zhou, K.; Cai, D. The influence of VSC-HVDC reactive power control mode on AC power system stability. Energies 2020,13,1677. [CrossRef]

99. Rao, H.; Zou, C.; Li, W.; Xu, S.; Li, Y.; Zhao, X.; Chen, J.; Zhou, Y. Oscillation between VSC-HVDC and AC grid: Phenomena, analysis and solution. In Proceedings of PURPLE MOUNTAIN FORUM 2019-International Forum on Smart Grid Protection and Control; Lecture Notes in Electrical Engineering; Springer: Cham, Switzerland, 2020; pp. 405-420.

100. Pipelzadeh, Y.; Chaudhuri, B.; Green, T.C. Control coordination within a VSC HVDC link for power oscillation damping: A robust decentralized approach using homotopy. IEEE Trans. Control Syst. Technol. 2013, 21, 1270-1279. [CrossRef]

101. Shao, Y.; Tang, Y. Voltage stability analysis of multi-infeed HVDC systems using small-signal stability assessment. In Proceedings of the IEEE PES Transmission and Distribution Conference and Exposition: Smart Solutions for a Changing World, New Orleans, LA, USA, 19-22 April 2010; pp. 1-6.

102. Rouzbehi, K.; Heidary Yazdi, S.S.; Shariati Moghadam, N. Power Flow Control in Multi-Terminal HVDC Grids Using a SerialParallel DC Power Flow Controller. IEEE Access 2018, 6, 56934-56944. [CrossRef]

103. Raza, A.; Mustafa, A.; Rouzbehi, K.; Jamil, M.; Gilani, S.O.; Abbas, G.; Farooq, U.; Shehzad, M.N. Optimal power flow and unified control strategy for multi-terminal HVDC systems. IEEE Access 2019, 7, 92642-92650. [CrossRef]

104. Li, B.; Liang, Y.; Wang, G.; Li, H.; Chen, X. A Control Parameter Design Method for Hybrid Multi-Terminal HVDC System. IEEE Access 2020, 8, 18669-18680. [CrossRef]

105. Grdenic, G.; Delimar, M.; Beerten, J. Comparative Analysis on Small-Signal Stability of Multi-Infeed VSC HVDC System with Different Reactive Power Control Strategies. IEEE Access 2019, 7, 151724-151732. [CrossRef]

106. Xue, Y.; Zhang, X.P. Reactive Power and AC Voltage Control of LCC HVDC System with Controllable Capacitors. IEEE Trans. Power Syst. 2017, 32, 753-764. [CrossRef]

107. Lee, G.S.; Kwon, D.H.; Moon, S.I.; Hwang, P.I. Reactive Power Control Method for the LCC Rectifier Side of a Hybrid HVDC System Exploiting DC Voltage Adjustment and Switched Shunt Device Control. IEEE Trans. Power Deliv. 2020, 35, 1575-1587. [CrossRef]

108. Renedo, J.; Garcia-Cerrada, A.; Rouco, L. Reactive-Power Coordination in VSC-HVDC Multi-Terminal Systems for Transient Stability Improvement. IEEE Trans. Power Syst. 2017, 32, 3758-3767. [CrossRef]

109. Yin, T.; Wang, Y.; Yue, B.; Xu, P.; Li, P.; Mei, N.; Xu, D. Impedance-Based Stability Analysis and Stabilization Control Strategy of MMC-HVDC Considering Complete Control Loops. IEEE Access 2020, 8, 142900-142915. [CrossRef]

110. Lyu, J.; Zhang, X.; Cai, X.; Molinas, M. Harmonic State-Space Based Small-Signal Impedance Modeling of a Modular Multilevel Converter with Consideration of Internal Harmonic Dynamics. IEEE Trans. Power Electron. 2019, 34, 2134-2148. [CrossRef]

111. Sun, J. Impedance-based stability criterion for grid-connected inverters. IEEE Trans. Power Electron. 2011, 26, 3075-3078. [CrossRef]

112. Harnefors, L.; Antonopoulos, A.; Norrga, S.; Angquist, L.; Nee, H.P. Dynamic analysis of modular multilevel converters. IEEE Trans. Ind. Electron. 2013, 60, 2526-2537. [CrossRef]

113. Ilves, K.; Antonopoulos, A.; Norrga, S.; Nee, H.P. Steady-state analysis of interaction between harmonic components of arm and line quantities of modular multilevel converters. IEEE Trans. Power Electron. 2012, 27, 57-68. [CrossRef]

114. Khazaei, J.; Beza, M.; Bongiorno, M. Impedance Analysis of Modular Multi-Level Converters Connected to Weak AC Grids. IEEE Trans. Power Syst. 2018, 33, 4015-4025. [CrossRef]

115. Shahsavarian, T.; Cao, Y.; Anagnostou, E.; Kalbfleisch, R. Novel modulated equivalent model of point-to-point LCC-based high voltage AC/DC/AC system for geomagnetic storm-induced unbalanced harmonic studies. Int. J. Electr. Power Energy Syst. 2020, 122, 106173. [CrossRef]

116. Ji, K.; Tang, G.; Yang, J.; Li, Y.; Liu, D. Harmonic Stability Analysis of MMC-Based DC System Using DC Impedance Model. IEEE J. Emerg. Sel. Top. Power Electron. 2020, 8, 1152-1163. [CrossRef]

117. Liu, H.; Sun, J. Modeling and analysis of DC-link harmonic instability in LCC HVDC systems. In Proceedings of the IEEE 14th Workshop on Control and Modeling for Power Electronics, Salt Lake City, UT, USA, 23-26 June 2013; pp. 1-9.

118. Céspedes, M.; Sun, J. Modeling and mitigation of harmonic resonance between wind turbines and the grid. In Proceedings of the IEEE Energy Conversion Congress and Exposition: Energy Conversion Innovation for a Clean Energy Future, Phoenix, AZ, USA, 17-22 September 2011; pp. 2109-2116.

119. Liu, H.; Sun, J. DC terminal impedance modeling of LCC-based HVDC converters. In Proceedings of the IEEE 14th Workshop on Control and Modeling for Power Electronics, Salt Lake City, UT, USA, 23-26 June 2013; pp. 1-8.

120. Zhang, Y. Investigation of Reactive Power Control and Compensation for HVDC Systems. Ph.D. Thesis, University of Manitoba, Winnipeg, MB, Canada, 2011. 
121. Pathak, A.K.; Sharma, M.P.; Bundele, M. A critical review of voltage and reactive power management of wind farms. Renew. Sustain. Energy Rev. 2015, 51, 460-471. [CrossRef]

122. Ni, X.; Gole, A.M.; Zhao, C.; Guo, C. An Improved Measure of AC System Strength for Performance Analysis of Multi-Infeed HVdc Systems Including VSC and LCC Converters. IEEE Trans. Power Deliv. 2018, 33, 169-178. [CrossRef]

123. Zhang, L.; Harnefors, L.; Nee, H.-P. Interconnection of Two Very Weak AC Systems by VSC-HVDC Links Using PowerSynchronization Control. IEEE Trans. Power Syst. 2011, 26, 344-355. [CrossRef]

124. Zhang, Z.; Xu, Z.; Xue, Y.; Tang, G. DC-Side Harmonic Currents Calculation and DC-Loop Resonance Analysis for an LCC-MMC Hybrid HVDC Transmission System. IEEE Trans. Power Deliv. 2015, 30, 642-651. [CrossRef]

125. Galland, O.; Eggenschwiler, L.; Horta, R.; Sattinger, W.; Favre-Perrod, P.; Roggo, D. Application of Resonance Analysis to AC-DC Networks. IEEE Trans. Power Deliv. 2018, 33, 1438-1447. [CrossRef]

126. Raza, M.; Prieto-Araujo, E.; Gomis-Bellmunt, O. Small-Signal Stability Analysis of Offshore AC Network Having Multiple VSC-HVDC Systems. IEEE Trans. Power Deliv. 2018, 33, 830-839. [CrossRef]

127. Xu, D.; Han, M.; Gole, A.M. Propagation of AC Background Harmonics in MMC HVdc Multiterminal Systems Due to Resonances and Mitigation Measures. IEEE Trans. Power Deliv. 2018, 33, 229-238. [CrossRef]

128. Yue, Y.; Xu, Q.; Shuai, Z.; He, Z.; Guo, P.; Li, Y.; Luo, A.; Shen, J. Low-frequency harmonic resonance analysis and suppression method of modular multilevel converter. IET Power Electron. 2018, 11, 755-763. [CrossRef]

129. Das, J.C. Power System Harmonics and Passive Filter Designs; Wiley-IEEE Press: Piscataway, NJ, USA, $2015 ;$ ISBN 9781118887059.

130. Guo, Q.; Yoon, M.; Kim, C.; Jang, G. Commutation failure and voltage sensitivity analysis in a hybrid multi-infeed HVDC system containing modular multilevel converter. Int. Trans. Electr. Energy Syst. 2016, 26, 2259-2271. [CrossRef] 